\title{
POLSCY SYNDONOLODZY. Z DZIEJÓW BADAŃ CAŁUNU TURYŃSKIEGO I ICH POPULARYZACJI
}

Utworzenie 21 X 2017 r. w Krakowie Polskiego Centrum Syndonologicznego (dalej: PCS), jako delegatury Międzynarodowego Centrum Syndonologicznego w Turynie, skłania przede wszystkim do wieloaspektowej refleksji nad dotychczasowymi osiągnięciami polskiej syndonologii, przypomnienia polskich badaczy całunu i popularyzatorów wiedzy o nim oraz wskazania na nowe perspektywy badawcze w obszarze stosunkowo nowej dyscypliny.

Zarówno syndonologia, jak i PCS swoje zainteresowania skupiają na całunie (gr. sindon, łac. sindone) przechowywanym od XVI w. w Turynie, zwanym całunem turyńskim. ${ }^{1}$ Tradycyjnie uważa się go za płótno pogrzebowe, którym posłużono się przy pochówku zdjętego z krzyża ciała Jezusa. Dlatego otaczano go kultem, jako jedną z najcenniejszych relikwii chrześcijańskich. Jednak część badaczy kwestionuje taką jego historię, przesuwając pochodzenie całunu na drugą połowę średniowiecza. ${ }^{2}$ Miał on wzmacniać rozwijającą się w tym czasie chrześcijańską pobożność pasyjną. Taka jego funkcja jest w zasadzie niekwestionowana. Natomiast przedmiotem dyskusji jest nierozpoznana historia całunu od jego początku (starożytność?) do późnego średniowiecza oraz wyjaśnienie powstania na nim odbicia ciała ludzkiego i jego identyfikacja z ciałem Jezusa zdjętym

Pisownia terminu ,całun turyński” nie jest jednorodna. Słownik języka polskiego PWN (zob. https://sjp.pwn.pl/szukaj/całun\%20turyński.html) zaleca pisania go małymi literami, choć nie jest sam w tym konsekwentny. W polskim edytorstwie prac syndonologicznych również dostrzega się tę różnorodność. Przyjąłem zatem zapis małymi literami, nie przydając temu wyborowi żadnych ideologicznych uwarunkowań.

2 Zob. A. J a n c z u k, J. K o p e ć, Całun Turyński, w: E. G i g i l e w i c z (red.), Encyklopedia katolicka, t. 2, Lublin 1976, kol. 1288-1290. 
z krzyża i złożonym do grobu, o czym przekaz odnajdujemy w najważniejszych źródłach do dziejów chrześcijaństwa - w kanonicznych Ewangeliach.

Celem powołanego $\mathrm{PCS}^{3} \mathrm{w}$ wymiarze badawczym jest zorganizowane uczestnictwo w toczącej się od końca XIX w. dyskusji na temat całunu turyńskiego. Główny impuls do niej dało wykonanie przez fotografa-amatora Secondo Pia (zob. fot. 1) w 1898 r. zdjęcia całunu. Ślad pozostawiony na płótnie przez owiniętego w nie człowieka okazał się po sfotografowaniu negatywowy, co skutkowało tym, że na wykonanym zdjęciu jego postać miała - ku zaskoczeniu i niedowierzaniu wielu - formę pozytywu. Próba rozwikłania zagadki, jak doszło do powstania takiego wizerunku, trwa do dzisiaj. Powstała odrębna dyscyplina naukowa, określana mianem ,syndonologii” lub „syndologii”, która tym się zajmuje. Prowadzone w jej obrębie badania mają charakter interdyscyplinarny. Podejmują je archeologowie, historycy sztuki, bibliści, patrologowie, historycy, filologowie, orientaliści, paleografowie, specjaliści od prawa rzymskiego i zwyczajowego żydowskiego, etnografowie, antropolodzy, numizmatycy, chemicy, fizycy, biolodzy, kryminolodzy i lekarze o różnych specjalnościach, zwłaszcza znawcy medycyny sądowej $i$ anatomii. Rzadko który z dostępnych nam artefaktów doczekał się tak wieloaspektowych badań.

Syndonologia jako dyscyplina naukowa zyskała także swoją organizację. Od 1939 r. odbywają się przeglądowe konferencje naukowe z tej dyscypliny. ${ }^{4}$ W 1950 r., z inicjatywy istniejącego od XVI w. w Turynie Bractwa Świętego Całunu, arcybiskup Turynu powołał Międzynarodowe Centrum Syndonologiczne, mające własne archiwum, bibliotekę i muzeum, które organizuje kongresy naukowe

3 Polskie Centrum Syndonologiczne swoje cele zdefiniowało w statucie; zob. http://calun.info/pcs/statut-pcs/ (dostęp: 25 I 2018).

4 Pierwszy miał charakter narodowy (włoski), a następne międzynarodowy. W drugim, obradującym w Rzymie w 1950 r., uczestniczył ks. prof. Eugeniusz Dąbrowski, który opisał jego przebieg i poruszaną tematykę oraz zawarł własną ocenę stanu badań nad całunem; E. D ą b ro w s k i, Sprawa Całunu turyńskiego, Studia biblijne, Warszawa $1952^{2}$, s. 171-187. 

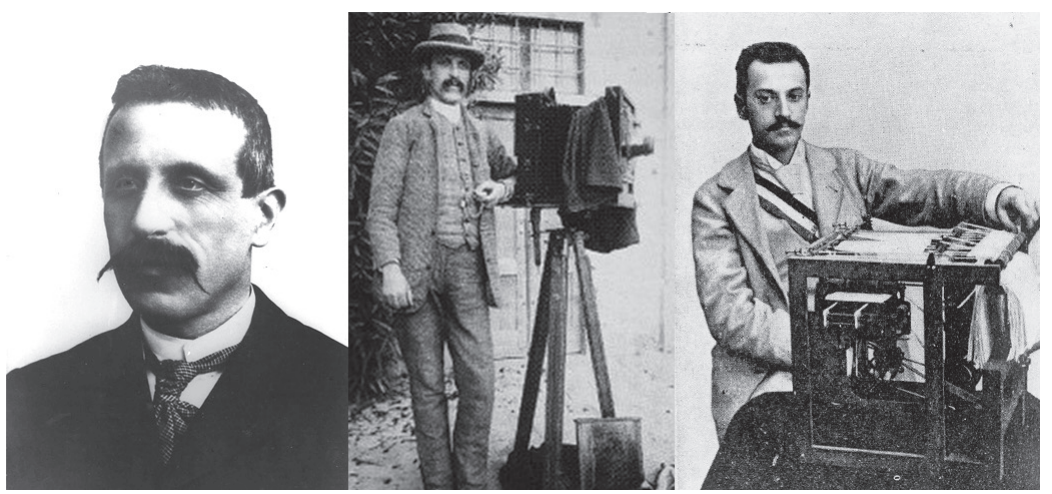

Fot 1. Od lewej: Secondo Pia, Giuseppe Enrie, Kazimierz Prószyński

oraz wydaje specjalistyczne pismo „Sindon”. Podobną funkcję pełni Rzymskie Centrum Syndonologiczne. Najpoważniejszą trudnością w prowadzeniu badań jest ograniczony dostęp do najważniejszego jej przedmiotu - całunu turyńskiego. Ponadto istnieje tylko wąska grupa osób, która o tym decyduje oraz stosuje niejasne procedury przy wyłanianiu badaczy i organizacji ich prac. W tym kontekście należy widzieć powstanie w USA projektu badawczego, realizowanego od lat siedemdziesiątych XX w. do 1998 r., pod nazwą Shroud of Turin Research Project (STURP). ${ }^{5}$ Skupiał on światowej sławy specjalistów, mających dostęp do najlepszych laboratoriów, w których prowadzono badania nad pobranymi z całunu próbkami. Wybranym członkom tego zespołu pozwolono na przeprowadzenie przez pięć dni (od 8 do 13 X 1978 r.) eksperymentów, pomiarów i testów na całunie w Turynie. W pewnym sensie kontynuatorem badań zespołu STURP jest założone przez fizyka Johna Jacksona w Colorado Springs The Turin Shroud Center of Colorado ${ }^{6}$ zbierające dokumentację na temat całunu i najnowsze wyniki badań syndologicznych w celu ich upowszechniania. Informacje te można znaleźć na stronie internetowej

5 Projekt powstał z inicjatywy o. Adama J. Otterbeina i ks. Pietro Rinaldi oraz Johna Jacksona i Erica Jumperta; zob. P. Baima Bollone, Całun Turyński. 101 pytań i odpowiedzi, Kraków 2002, s. 272-275.

6 Tamże, s. 278. 
centrum http://www.shroudofturin.com. Na uwagę zasługuje zwłaszcza jego działalność edukacyjna, mogąca uchodzić za wzorcową w skali światowej.

Udział Polaków w badaniach syndonologicznych był dotąd znikomy, a w obszarze programów (a może raczej indywidualnych przedsięwzięć) edukacyjno-duszpasterskich, związanych z całunem, nieliczny, zindywidualizowany i zdezintegrowany. Po części ten stan obrazuje załączona do niniejszego artykułu polska bibliografia syndonologiczna. Zresztą niemało trudności nastręcza całościowe opisanie polskiej aktywności zarówno badawczej na polu syndonologii, jak i edukacyjno-duszpasterskiej.

Do 1939 r. zupełnie sporadycznie pojawiały się publikacje w języku polskim na temat całunu turyńskiego. Poza najwcześniejszą drobną wzmianką z 1931 r. z „Kuriera Poznańskiego”, zapowiadającą wystawienie całunu w tymże roku w Turynie, nie udało się odnaleźć wcześniejszych publikacji na jego temat. Rok 1932 przyniósł pierwszą piętnastostronicową broszurę wydaną w Warszawie w drukarni F. Wyszyńskiego pt. Niestychane odkrycie naukowe. Prawdziwa

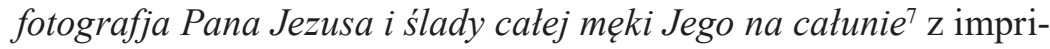
matur Kurii Metropolitalnej Warszawskiej. Jej autorem był Kazimierz Prószyński (1875-1945; fot. 1), który używał również inicjałów K. Pr., znany polski inżynier mechanik, wynalazca i konstruktor aparatów filmowych, pionier kinematografii światowej, zamordowany przez Niemców w obozie koncentracyjnym Mauthausen-Gusen w wieku 69 lat. $^{8}$

Bezpośrednią inspiracją do zainteresowania się całunem było jego wystawienie na widok publiczny w katedrze w Turynie w 1931 r. oraz wykonanie jego zdjęć przez Giuseppe Enriego (fot. 1), a wcześniej, w 1898 r., przez fotografa-amatora Secondo Pia, które ujawniły, że

7 Praca ta drukowana była wcześniej w „Gazecie Świątecznej”, ale do niniejszego wydania - jak zaznacza autor we wstępie - dodane zostało sporo uzupełnień i wyjaśnień (s. 3).

8 Zob. J. K u b i a t o w s k i, Prószyński Kazimierz (1875-1945), w: Polski słownik biograficzny, t. 28, Kraków 1984-1985, s. 560-563. 
odbicie postaci człowieka na płótnie jest - ku zaskoczeniu wszystkich i niedowierzaniu niektórych - negatywem. Kazimierz Prószyński dołączył pięć wybranych rycin tych zdjęć oraz opis całunu i przedstawił próby wyjaśnienia powstania negatywowego odbicia, podążając za naukowymi pracami Arthura Lotha Le portrait de N.-S. Jésus-Christ d'après le Saint-Suaire de Turin avec reproduction photographiques (ok. 1900) i Paula Vignona Le Linceul du Christ $\left(1902^{2}\right)$. To bodaj pierwszy obszerniejszy opis po polsku całunu, zmierzający do konkluzji, że można powiedzieć - po przeszło trzydziestu latach od wykonania jego pierwszego zdjęcia - że jest on całunem Chrystusa, a nie sztucznym malowidłem, jak sądzono przez lata. Na uwage zasługuje i to, że w rok po polskim wydaniu broszury jej przekład opublikowano również po angielsku w Londynie pt. The authentic „Photograph” of Christ (1933).

W 1937 r. ukazała się w Księgarni Św. Wojciecha, z imprimatur Poznańskiej Kurii Metropolitalnej, w nakładzie 4 tys. egzemplarzy (wyd. 1) szersza prezentacja całunu turyńskiego i badań nad nim pt. Święty całun z Turynu. Męka Pańska w oświetleniu nauki. Autorem jej był Czech, Rudolf W. Hynek (1883-1952), a jego pracę Umučeni Páně vědou odhalené (Praha 1936) spolszczył i opracował Stanisław Karwowski. W rok później wydrukowano drugie jej wydanie (rozszerzone), na nowo opracowane na podstawie trzeciego wydania czeskiego R.W. Hynka Kristova tvář a muka (Praha 1937) oraz drugiego wydania niemieckiego Golgotha - Wissenschaft und Mystik (Karlsruhe 1936). Pojawienie się książki R.W. Hynka po polsku związane było z powiększającym się zainteresowaniem tematyką dotyczącą całunu turyńskiego. Obok badającej całun włoskiej komisji, dość szybko ukonstytuowała się komisja francuska pod przewodnictwem prof. P. Vignona, wspomnianego powyżej, oraz czechosłowacka i północnoamerykańska. W czechosłowackiej wiodącą pozycję miał dr R.W. Hynek (znany także jako Ralph Waldo), czeski lekarz, który pozostawił po sobie niemałą spuściznę piśmienniczą z zakresu medycyny, psychologii, magii, okultyzmu i... (po przejściu na katolicyzm) syndonologii. Całunem turyńskim zajął się w zasadzie z dwóch motywów. Po pierwsze uznał, że zeświecczonemu społeczeństwu, 
które zainteresowało się niezwykłym odkryciem z Turynu, należy uświadomić najpierw, że Jezus to postać historyczna, czego nie tylko dowodzą antyczne świadectwa Tacyta, Swetoniusza, Pliniusza Młodszego, Józefa Flawiusza oraz liczne źródła wczesnochrześcijańskie, ale także całun z Turynu. Całun sfotografowany po raz drugi w $1931 \mathrm{r}$. przez G. Enriego, który udostępnił wykonane zdjęcia R.W. Hynkowi do jego książki, dał czeskiemu badaczowi podstawę do stwierdzenia, że „nauka współczesna fotografuje dziś, po dziewiętnastu stuleciach, Ciało Chrystusa" (wyd. 2, s. 3). Drugim motywem było pragnienie wprowadzenia czytelnika w misterium męki Jezusa i przypomnienie jej soterycznego znaczenia (s. 4) oraz potwierdzenie na nowo piękna oraz historyczności wiary chrześcijańskiej (s. 5).

Stanisław Karwowski (1906-1940), jako trzydziestoletni polski lekarz, doktor nauk medycznych Uniwersytetu Adama Mickiewicza w Poznaniu, specjalizujący się w laryngologii, uznał, że pracę R.W. Hynka należy udostępnić polskiemu czytelnikowi, aby katolicka Polska - jak napisze w przedmowie do jej drugiego wydania - nie znalazła się w popularyzacji całunu „na szarym końcu” (s. VIII). W latach 1934-1936 pracował on w Klinice Laryngologii na Uniwersytecie Karola w Pradze i wówczas zainteresował się publikacjami dr. R.W. Hynka. ${ }^{9}$ Ś więty całun przetłumaczył w latach 1936-1937, kiedy był już także wykładowcą medycyny pastoralnej w Wyższym Seminarium Duchownym w Poznaniu. Zawartą w książce wiedzę o tajemniczym wizerunku Jezusa popularyzował także przez liczne wykłady i prelekcje, komentując ją z punktu widzenia medycznego.

Na jego wykład pt. Całun turyński oczyma lekarza trafił przypadkowo dr med. Stanisław Waliszewski, anatom i chirurg z Poznania i Rogoźna Wielkopolskiego. Zafascynowany - jak później relacjonował - ,pięknie i artystycznie namalowanym całunem” (taką kopią posługiwał się S. Karwowski) poświęcił całe życie temu zagadnieniu i stał się znanym w świecie polskim syndonologiem. ${ }^{10}$ Doktor

9 Por. A. K a r w o w s k i, Wielkopolska gałąź rodziny Karwowskich, www. madalinski.info/media/11858.pdf (dostęp: 18 XII 2017).

10 Tamże. 


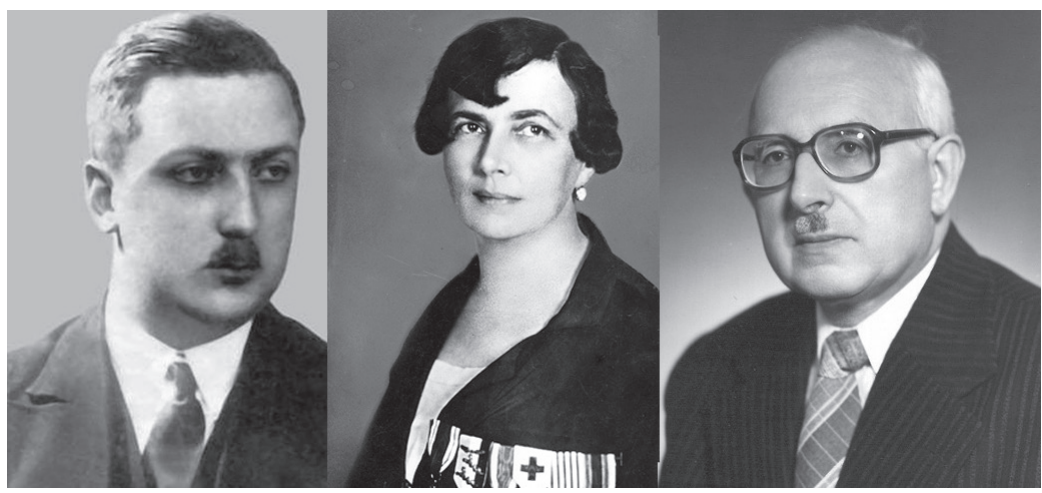

Fot 2. Od lewej: Stanisław Karwowski, Wanda Ładzina, Stanisław Waliszewski

S. Karwowski, wgłębiając się w misterium śmierci Jezusa z całunu, nie wiedział, że sam w pewnej mierze doświadczy wkrótce niezwykłego cierpienia. Tuż przed wybuchem wojny dostał przydział, jako lekarz w randze podporucznika, do szpitala wojskowego w Białowieży. Następnie został osadzony przez Rosjan w obozie dla polskich oficerów w Ostaszkowie, zamordowany w wieku 34 lat strzałem w tył głowy w więzieniu NKWD w Twerze w kwietniu 1940 r. i pochowany w Miednoje (dziś Polski Cmentarz Wojenny).

Ostatnia przedwojenna broszura dotycząca całunu z Turynu ukazała się w Polsce w marcu 1939 r. Jej autorką była Wanda Ładzina (1880-1966, fot. 2), instruktorka sanitarna, posłanka na Sejm II RP (1922-1927) oraz działaczka społeczna i polityczna. ${ }^{11}$ Pod koniec marca 1939 r. opublikowała w Warszawie ponad siedemdziesięciostronicową rozprawkę pt. Ziemska postać umęczonego Chrystusa wedtug całunu turyńskiego, z imprimatur Metropolitalnej Kurii Warszawskiej oraz dedykacją kard. Maurilio Fossati, arcybiskupa Turynu: „Daję moje błogosławieństwo Szanownej Pani Wandzie Ładzinie dla Jej owocnej apostolskiej pracy nad rozszerzaniem czci św. Całunu wśród szlachetnego Narodu Polskiego". Podpisała ją jako korespondentka na Polskę Towarzystwa „Cultores Sanctae Sindonis”

${ }^{11}$ Por. Z. D $\nmid$ u ż e w s k a - K a ń s k a, Ładzina ze Szczuków Wanda Władysława Józefa (1880-1966), w: Polski słownik biograficzny, t. 18, s. 188-189. 
(Czcicieli Św. Całunu). Bezpośrednią inspiracją do jej powstania była paryska wystawa w 1937 r., na której w watykańskim pawilonie wystawiano fotografię całunu wykonaną przez G. Enriego. Wzbudzała ona olbrzymie zainteresowanie i wyzwalała wśród oglądających potrzebę okazywania Jezusowi czci.

Autorka, mając świadomość tego, że swą pracą naśladuje tylko publikacje dr. R.W. Hynka oraz dr. S. Karwowskiego i przywołuje w niej badania P. Vignona (jak wyżej) i P. Barbeta Les cinq plaies du Christ (Paris 1935?), za najważniejsze zadanie postawiła sobie spopularyzowanie w Polsce i wśród Polonii całunu turyńskiego jako świadka wiary „piątej Ewangelii” oraz relikwii równej krzyżowi Chrystusa. Temu też służyły liczne odczyty wygłaszane przez nią w kraju i zagranicą.

Tak w zasadzie dobiegł końca przedwojenny okres polskiej aktywności syndonologicznej, który koncentrował się na popularyzacji całunu, pierwszych próbach wyjaśniania związanych z nim kwestii, zwłaszcza w aspektach historycznych i medycznych, oraz propagowania jego kultu jako świętej relikwii, do czego zachęcali papieże początku XX w.

Po zakończeniu wojny w 1945 r. dość szybko nastąpił w Polsce powrót do problematyki związanej z całunem turyńskim. Można w tym okresie, liczącym ponad siedemdziesiąt lat, wyróżnić publicystykę syndonologiczną, prace popularno-naukowe (w tym druki zwarte), rzadko pojawiające się artykuły naukowe oraz tłumaczenia - głównie z włoskiego - (popularno-)naukowej literatury. Na tym tle usytuować należy aktywność pięciu wyróżniających się polskich syndonologów drugiej połowy XX w., którzy pozostawili po sobie dorobek piśmienniczy (różnej wielkości), angażowali się w popularyzację wiedzy o całunie, brali udział w krajowych i międzynarodowych konferencjach syndonologicznych oraz wpłynęli na organizację i kierunki tej dyscypliny w Polsce, a także uczynili rozpoznawalną polską myśl syndonologiczną w wymiarze międzynarodowym. Należą do nich dr med. Stanisław Waliszewski, który stanowi pomost między przedwojenną a powojenną syndonologią polską, prof. dr hab. Władysław Fenrych, biochemik związany również jak S. Waliszewski z poznańskim środowiskiem naukowym, ks. prof. dr hab. Jerzy Chmiel, 
znany biblista z Papieskiego Wydziału Teologicznego a następnie Uniwersytetu Papieskiego Jana Pawła II w Krakowie oraz ostatni z tej grupy, mgr inż. Jerzy Dołęga-Chodasiewicz, leśnik z obszaru świętokrzyskiego, długo związany z klasztorem na Świętym Krzyżu, oraz Zenon Ziółkowski z Warszawy, dziś już nestor polskiej biblistyki i autor prac popularnoreligijnych. Niemały też wpływ na polską syndonologię wywarł papież Jan Paweł II, ${ }^{12} \mathrm{z}$ którego inicjatywy powołano w 1981 r. w Krakowie przy Polskim Towarzystwie Teologicznym Studium Syndonologiczne (Studium Sindonologicum Cracoviae). Od początku kierował nim znany polski biblista ks. doc. dr hab. Jerzy Chmiel. Nowością na tym etapie historii polskiej syndonologii było włączenie się w nią po 1945 r., obok lekarzy medycyny, biochemików i fizyków, także biblistów (księża profesorowie W. Gronkowski, K. Borowicz, E. Dąbrowski, W. Chrostowski, L. Stefaniak, oraz prof. M. Wojciechowski - zob. bibliografia sub verbo), spośród których tylko dwaj (wspomniani J. Chmiel i Z. Ziółkowski) traktowali swe zainteresowania całunem za stałe, a nie efemerycznie.

Stanisław Waliszewski (1912-2011, fot. 2) swoje zainteresowanie całunem zawdzięczał spotkaniu z dr. Stanisławem Karwowskim. Zapadło mu ono głęboko w pamięć, bo wielokrotnie je przywoływał we wspomnieniach: „Było to w niedzielę Męki Pańskiej 1938 roku. W drodze powrotnej z kościoła do domu, zostałem niemal siłą wciągnięty przez tłum ludzi do pasażu kina «Słońce» na Placu Wolności w Poznaniu. Z rozwieszonych plakatów dowiedziałem się, że dr med. Stanisław Karwowski będzie miał wykład o Całunie turyńskim. Zaciekawiony problematyką, stałem przez półtorej godziny, pilnie słuchając profesora". ${ }^{13}$

12 O związkach kard. K. Wojtyły/Jana Pawła II z całunem zob. J. C h m i e 1, Jan Pawet II i Całun Turyński, w: S. K o p e r e k, S. S z c z u r (red.), Servo veritatis. Materiały międzynarodowej konferencji dla uczczenia 25-lecia pontyfikatu Jego Świątobliwości Jana Pawła II, Uniwersytet Jagielloński, 9-11 października 2003 r., Wydawnictwo Naukowe Papieskiej Akademii Teologicznej, Kraków 2003, s. $763-766$.

13 Zob. S. W a 1 i s z e w s k i, Całun turyński dzisiaj, Kraków 1994³, s. 197. 
Po przeszło siedemdziesięciu latach od tego wydarzenia wyznał, że całun stał się jego życiową pasją - jak mówił - ,zrodzoną z miłości do Jezusa". ${ }^{14}$ Rozpoczynał ją jako młody lekarz z trzyletnim stażem, a po wojnie, kiedy już zabrakło jego mistrza, sam systematycznie odtwarzał, po dr. Karwowskim, i zbierał dokumentację dotyczącą tego niezwykłego płótna, współtworząc zręby polskiej syndonologii i z czasem dołączając do grona międzynarodowych specjalistów badaczy całunu. Początkowo był - jak wspomina - „całunowym katechistą”, objeżdżając z wykładami liczne szkoły, poczynając od rodzinnego Rogoźna Wielkopolskiego. Przełomowy w tej działalności popularyzatorskiej stał się rok 1958, kiedy to przybył do Krakowa na zaproszenie wybitnego biblisty i orientalisty ks. prof. Aleksego Klawka, pochodzącego również z Rogoźna Wielkopolskiego. Jego wykłady wygłaszane były nie tylko do seminarzystów wyższych seminariów duchownych (częstochowskiego, śląskiego i krakowskiego), ale też do profesury Uniwersytetu Jagiellońskiego, co spotykało się z dużym zainteresowaniem i wręcz entuzjazmem. To go utwierdziło w przekonaniu o celowości wysiłków, jakie podejmował niejako pobocznie. Jego zasadniczą specjalnością, jako lekarza, była anatomia i chirurgia (w wieku 36 lat uzyskał doktorat z zakresu nauk medycznych). Syndonologia była pasją, którą łączył z profesjonalizmem medycznym. Od końca lat pięćdziesiątych jego działalność miała już nie tylko charakter lokalny, lecz ogólnopolski. Pomógł mu w tym ks. A. Klawek, który w latach 1953-1954 opublikował jego obszerny artykuł na łamach naukowego czasopisma teologicznego „Ruch Biblijny i Liturgiczny”, ${ }^{15}$ którego był członkiem założycielem i redaktorem naczelnym (do 1954 r.).

14 Por. A. S u w a r t, Całun mojego życia, https://www.przewodnik-katolicki. pl/Archiwum/2009/Przewodnik-Katolicki-31-2009/Historia/Calun-mojego-zycia (dostęp: 2 I 2018).

15 S. W a 1 i s z e w s k i, Uwagi o Całunie Turyńskim, Ruch Biblijny i Liturgiczny 6(1953) nr 1-6, s. 50-74; addenda s. 223; Ruch Biblijny i Liturgiczny 7(1954) nr 3-6, s. $68-106$. 
Kolejną swoistą cezurą w uprawianiu syndonologii były lata siedemdziesiąte XX w. Inspirującą rolę w życiu S. Waliszewskiego odegrał wówczas kard. Karol Wojtyła, metropolita krakowski. To on wydatnie wsparł jego starania o uczestnictwo w Międzynarodowym Kongresie Syndonologicznym w Turynie (1978), wyposażając go w napisany odręcznie po włosku list polecający, który otwierał dr. Waliszewskiemu drogę do grona światowych badaczy całunu, tym bardziej że jego autor wybrany został wkrótce papieżem.

Stanisław Waliszewski wykorzystał swoją szansę. Wyprowadził polską syndonologię na arenę międzynarodową, sam będąc powołany na członka korespondenta Międzynarodowego Centrum Badań nad Całunem w Turynie. W jeszcze większym stopniu rozbudził w Polsce zainteresowanie całunem i wychował całe pokolenie polskich syndonologów, wygłaszając niezliczone odczyty o całunie i popularyzując o nim wiedzę. Pozostawił po sobie liczne publikacje (zob. załączoną bibliografię sub verbo), w tym najważniejszą, wielokrotnie wznawianą, Całun turyński dzisiaj $(1987,1988,1994)$, która była pierwszą powojenną książką proweniencji polskiej na temat całunu turyńskiego, odpowiadającą na najnowsze wyzwania badawcze. Wprawdzie w 1978 r. wydano już przetłumaczoną na język polski pracę Iana Wilsona Całun Turyński (tłum J. Piątkowska, Kraków: Wydawnictwo Apostolstwa Modlitwy), ${ }^{16}$ ale kolejne lata przyniosły nowe wyniki badawcze, $w$ tym prowadzone $w$ ramach projektu STURP. Wskazały one na trzy cechy wizerunku na całunie: trójwymiarowość, (bez) kierunkowość i powierzchniowość, które świadczyły o jego unikalności. ${ }^{17} \mathrm{~W}$ pracy polskiego syndonologa znalazło to odzwierciedlenie. Don Piero Coero Borga, sekretarz Międzynarodowego Centrum Badań nad Całunem Turyńskim, pisząc przewodni list do pracy S. Waliszewskiego, docenił w niej również medyczne aspekty badań

16 W tymże samym roku ukazała się po raz pierwszy po angielsku w USA. Do dziś wielokrotnie wznawiana (także po polsku) należy do klasyki popularyzatorskiej literatury syndonologicznej; por. A. P ol k ow s k i, Posłowie od thumacza, w: I. W i 1 s o n, Całun Turyński, Instytut Wydawniczy Pax, Warszawa 1983, s. 334.

17 Por. http:www.shroud.com/78conclu.htm (dostęp: 2 I 2018). 
prowadzonych przez autora oraz osobisty jej charakter, który wyraził się nie tylko w dzieleniu swoją wiedzą o całunie, ale świadectwem osobistej wiary w Zmartwychwstałego i ślady Jego męki zawarte na Jego pośmiertnym płótnie. W ten sposób dawał wyraz swemu przeświadczeniu i wierze, że całun jest najświętszą i najczcigodniejszą relikwią chrześcijańską, obrazującą miłość Jezusa do człowieka, a dla niego osobiście niejako „tarczą ochronną”, która zapewniła mu długowieczność (zmarł mając blisko sto lat). ${ }^{18}$ Jego pragnieniem było, aby w Krakowie, umiłowanym mieście Ojca Świętego Jana Pawła II, powstał rozbudowany Ośrodek Naukowo-Informacyjny, będący centrum syndonologicznym w Polsce. Cieszyło go już powołanie przy Polskim Towarzystwie Teologicznym Studium Syndonologicznego, do czego się też sam przyczynił. Nie dożył jednak czasu spełnienia swoich marzeń, które ziściły się dopiero w pięć lat po jego śmierci.

Współpracownikiem dr. S. Waliszewskiego od lat siedemdziesiątych XX w. był prof. dr hab. Władysław Fenrych (1927-2002, fot. 3) z Akademii Medycznej w Poznaniu, na której wykładał biochemię farmaceutyczną, a wcześniej hematologię i transfuzjologię. W zakresie syndonologii łączyło ich instytucjonalnie krakowskie Studium Syndonologiczne.

Władysław Fenrych dał się poznać jako znawca całunu, zwłaszcza w obszarze związanych z nim badań hematologicznych. Stanisław Waliszewski zaprosił go do współpracy nad wspomnianą wyżej książką, powierzając mu opracowanie rozdziału o śladach krwi na całunie. On również do trzeciego, uzupełnionego wydania książki Całun Turyński dzisiaj (1993), napisał polemikę w obronie autentyczności całunu, wykazując że badania przeprowadzone w 1988 r. w trzech ośrodkach - Tuckson, Oxford i Zurych - są niezgodne z metodologią naukową, a wydany przez badaczy werdykt nieuzasadniony. Aktywność syndonologiczną prof. Fenrych wykazywał nie tylko przez publikacje (zob. załączona bibliografia sub verbo), ale

18 Por. M. Pabis, Tego chce ode mnie Bóg, Cuda i Łaski Boże. Miesięcznik Rodzin Katolickich 4/ 2007, http://www.cudaboze.pl/2007/rozdzial. php? numer=4\&rozdzial=2 (dostęp: 2 I 2018). 


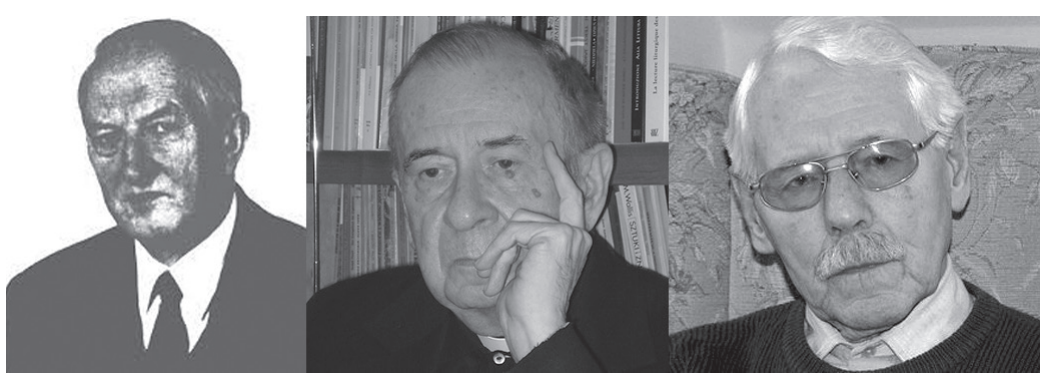

Fot 3. Od lewej: Władysław Fenrych, Jerzy Chmiel, Jerzy Dołęga-Chodasiewicz

także przez udział w sympozjach krajowych (np. w 1991 r. w Łodzi zorganizowanym przez bp. Adama Lepę), jak i międzynarodowych (1993 - Rzym, 1998 - Turyn, 2000 - Orvieto). Utrzymywał również kontakty naukowe z syndonologami amerykańskimi ze stowarzyszenia STURP. W 2000 r. zorganizował w Poznańskim Towarzystwie Naukowym spotkanie ze znaną syndonolożką włoską Emanuelą Marinelli, której książka Całun. Obraz ,niemożliwy” ukazała się w polskim tłumaczeniu W. Polczyka we Wrocławiu (1999). Jeszcze w 2001 r., na rok przed śmiercią, referował w Polsce wyniki światowego kongresu syndonologicznego w Dallas. ${ }^{19}$

Trzecim, z najbardziej znaczących polskich syndonologów XX w., był ks. doc. dr hab. Jerzy Chmiel (1936-2016, fot. 3) z Papieskiego Wydziału Teologicznego w Krakowie/Uniwersytetu Papieskiego Jana Pawła II, wybitny biblista i pierwszy kierownik powołanego przy Polskim Towarzystwie Teologicznym w Krakowie 9 X 1981 r. Studium Syndonologicznego.

Było to spełnienie życzenia papieża Jana Pawła II, wyrażonego za pośrednictwem kard. Franciszka Macharskiego, metropolity krakowskiego. ${ }^{20}$ Celem studium jest - jak to stanowi jego

19 Por. S. W a l i s z e w s k i, Badacz Całunu Turyńskiego, https://www.przewodnik-katolicki.pl/Archiwum/2003/Przewodnik-Katolicki-35-2003/Archidiecezja-Poznanska/Badacz-Calunu-Turynskiego (dostęp: 9 I 2018).

${ }^{20}$ Wspomina o tym J. D ołęg a - Chodasiew ic z, Najnowsze doniesienia [o catunie], rozm. przepr. Katarzyna Urban, Nasza Arka. 
Regulamin - „koordynacja badań naukowych polskich syndonologów, koordynacja działalności informacyjno-popularyzatorskiej na temat całunu wśród społeczeństwa oraz utrzymywanie kontaktów z podobnymi placówkami w kraju i za granicą". ${ }^{21}$ Do jego najbliższych współpracowników należeli: S. Waliszewski, W. Fenrych i J. Dołęga-Chodasiewicz. W ramach studium wygłaszano w różnych miejscach Polski liczne konferencje naukowe i popularnonaukowe po kościołach oraz budynkach kościelnych. Okres stanu wojennego nie sprzyjał początkowo prowadzeniu działalności regulaminowej, ale już w 1984 r. ks. J. Chmiel zorganizował w Wyższym Seminarium Duchownym Krakowskim sesję syndonologiczną, na której wygłosił odczyt Teologia Całunu Turyńskiego - próba zarysu. Podobna sesja odbyła się w rok później. Tym razem tematem jego wystąpienia było Świadectwo Czwartej Ewangelii - nowe propozycje egzegetyczne. Z jego inicjatywy członkowie Studium uczestniczyli w kolejnych latach w wielu konferencjach zagranicznych oraz zabierali głos w sprawie kontrowersyjnych wyników badań całunu ogłoszonych w 1988 r., broniąc jego starożytności. Z czasem Studium, dzięki życzliwości prof. E. Marinelli, utrzymywało stały kontakt z rzymskim Collegamento pro Sindone oraz skompletowało dokumentację z dwóch międzynarodowych kongresów syndonologicznych (Turyn 1998 i Orvieto 2000).

Poglądy ks. J. Chmiela na całun turyński ewoluowały. U początku swego nim zainteresowania cechował go, jak wielu historyków i biblistów, sceptycyzm. Wraz ze zgłębianiem problematyki - jak napisał w 1980 r. - „przekonał się, niejako «nawrócił się» do niego”. ${ }^{22}$ Stał się on dla niego znakiem męki i zmartwychwstania Jezusa, choć, pisząc przywołany powyżej artykuł, przy tym stwierdzeniu pozostawił

Miesięcznik Rodzin Katolickich 4/2010, http://www.nasza-arka.pl/2010/rozdzial. php?numer=4\&rozdzial=8 (dostęp: 13 I 2018).

${ }_{21}$ Zob. J. C h m i e 1, 15-lecie istnienia Studium Syndonologicznego, Ruch Biblijny i Liturgiczny 49(1996) nr 3, s. 202.

${ }_{22}$ Te n ż e, Całun Turyński znakiem męki i zmartwychwstania Jezusa? Tygodnik Powszechny 34(1980) nr 15, s. 3. 
świadomie znak zapytania po to, by całun był dla każdego, kto się do niego na różny sposób zbliża, wyzwaniem hermeneutycznym niepokojącym człowieka. ${ }^{23}$ Aktywność syndonologiczna ks. J. Chmiela była o wiele rozleglejsza, niż to zostało tutaj przedstawione, a pozostawiony przez niego dorobek piśmienniczy (zob. bibliografia sub verbo) jest tylko w niewielkim stopniu jej odbiciem. Jednym z najważniejszych jego osiągnięć w obszarze syndonologii było zaszczepienie tej problematyki całemu pokoleniu osób duchownych i świeckich, któremu całun turyński stał się znany jako cenna relikwia chrześcijańska, niebędąca wprawdzie źródłem wiary, ale ją pogłębiająca.

Jednym z dwóch żyjących współpracowników ks. J. Chmiela był mgr inż. Jerzy Dołęga-Chodasiewicz (fot. 3), absolwent SGGW w Warszawie, leśnik w lasach gospodarczych w Białostockiem, a następnie kustosz Muzeum Przyrodniczo-Leśnego Świętokrzyskiego Parku Narodowego na Świętym Krzyżu (od 1969 r.), obecnie emeryt mieszkający w Kielcach. Jego zainteresowanie całunem zaczęło się przypadkowo w warszawskich Łazienkach, gdy szedł do obserwatorium astronomicznego Uniwersytetu Warszawskiego i spotkał się ze znanym radioastronomem z Torunia (później z Krakowa), prof. Konradem Rudnickim, który wręczył mu fotografię twarzy człowieka z całunu turyńskiego. Od tego czasu myśl o całunie - jak wielokrotnie wspomina - towarzyszyła mu przez całe życie. Za pośrednictwem dominikanina, o. Honoriusza Kowalczyka z Poznania, skontaktował się z dr. S. Waliszewskim, który zaprosił go do współpracy w badaniach syndonologicznych i popularyzacji wiedzy o całunie. Jerzy Dołęga-Chodasiewicz wykazywał się w tym zakresie niezwykłą aktywnością, pisując artykuły w pismach lokalnych (zob. bibliografia sub verbo), głosząc liczne wykłady o całunie, m.in. dla nowicjuszy w klasztorze Misjonarzy Oblatów Maryi Niepokalanej na Świętym Krzyżu oraz w innych placówkach kościelnych, i współpracując ze Studium Syndonologicznym w Krakowie.

23 Tamże, s. 7. 


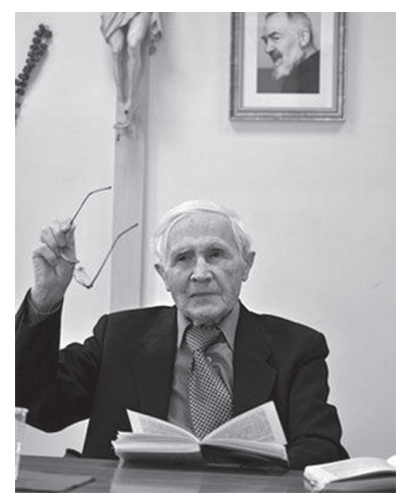

Fot 4. Zenon Ziółkowski

Miał także swój wkład w przygotowywaną przez S. Waliszewskiego książkę Całun turyński dzisiaj. Opracował wspólnie z jej autorem rozdział Dlaczego Człowieka z całunu możemy utożsamiać z Jezusem Chrystusem, a samodzielnie rozdziały Trójwymiarowy obraz catunu i Historia Catunu turyńskiego w pierwszym tysiacleciunajnowsze studia $i$ analiza przekazów źródłowych oraz ostatni, wspólnie z Bolesławem Makiejem, Najnowsze hipotezy utworzenia się wizerunku na Catunie turyńskim. Uczestniczył też w 1993 r. wraz z prof. W. Fenrychem w Międzynarodowym Sympozjum Naukowym o Całunie w Rzymie, składając następnie obszerne sprawozdanie z niego w Krakowie w gronie polskich syndonologów.

Wskazaną grupę najaktywniejszych polskich syndonologów XX w. zamyka Zenon Ziółkowski (ur. 1927, fot. 4), mający na swoim koncie najbogatszy dorobek piśmienniczy. Źródłem jego zainteresowań była dłuższa obecność w Turynie i możliwość kontaktu z wystawianym całunem oraz uczestnictwa w wizytach papieża Jana Pawła II w tym mieście.

Jego pierwsze publikacje pojawiły się w pierwszej połowie lat siedemdziesiątych XX w. Brał udział w zagranicznych sympozjach na temat całunu, w tym w Londynie w 1977 r. Relacjonował następnie w polskiej prasie papieską wizytę z 1980 r. w Turynie. Zestawił polskie publikacje syndonologiczne, których spis bibliograficzny dołączono w 1983 r. do przetłumaczonej na język polski pracy I. Wilsona (zob. szerzej bibliografia sub verbo). Rok 1994 przyniósł jego pierwsze większe samoistne opracowanie popularno-naukowe pt. Spór o Całun Turyński. Relikwia męki Pańskiej w świetle najnowszych badań naukowych (Warszawa: Oficyna Adam, 1996²), a w 2011 r. opublikował drugą książkę o całunie pt. Całun Turyński. Milczacy świadek męki, śmierci i zmartwychwstania (Warszawa: 
Oficyna Adam), w której zapoznaje z najnowszymi ustaleniami dotyczącymi turyńskiego płótna, sam opowiadając się za jego autentycznością i starożytnym pochodzeniem. W jego przekonaniu jest ono całunem Jezusa, w którym złożono Jego ciało do grobu. Zenon Ziółkowski nie stroni w swych publikacjach, jak i działalności popularyzacyjnej, od dewocyjnego ujęcia przedstawianej problematyki. Jest to cecha całego jego piśmiennictwa religijnego, obejmującego obszar biblistyki, historii i duchowości Jana Pawła II, o. Pio, s. Faustyny oraz syndonologii.

Podsumowując osiągnięcia polskiej syndonologii XX w., należy docenić podjęcie przez nią tematyki całunu turyńskiego w pierwszych dekadach po wykonaniu jego pierwszych fotografii. Na tym etapie młoda dyscyplina miała tylko nielicznych protektorów, którzy zapoznawali polskie społeczeństwo z rezultatami badań włoskich i francuskich, posiłkując się przy tym publicystyką czechosłowacką. Dzięki nim przedwojenna Polska nie stała się ,pustynią” w obszarze syndonologii. Po II wojnie światowej dość szybko wróciło zainteresowanie całunem oraz pojawiło się piśmiennictwo naukowe i popularne z nim związane. W tym kontekście nieostre staje się określenie ,syndonolog”. Nie jest nim tylko badacz, który pozostawił po sobie piśmiennictwo o tej tematyce. Ze źródeł wynika, że niemała grupa polskich uczonych interesowała się badaniami nad całunem, ale nie podejmowała tego tematu w swej naukowej twórczości. Jednocześnie wyraźniej zarysował się podział na zwolenników widzenia w całunie relikwii (większość) oraz sceptyków, traktujących go za wytwór średniowieczny, który - co najwyżej miał wspomagać rozwój pobożności pasyjnej w następnych wiekach. Nie wolno też zapomnieć o specyfice politycznej sytuacji Polski w okresie od 1944 do 1989 r., w której wolności obywatelskie, w tym w wymiarze religijnym, były znacznie ograniczone. Popularyzacja wiedzy o całunie dokonywała się akcyjnie i była prowadzona przez nielicznych prelegentów, o dobrym przygotowaniu merytorycznym, ale inwigilowanych - jak wspomina S. Waliszewski - przez służbę bezpieczeństwa. Mimo wszystko udało się im nawiązać kontakt ze światowymi centrami syndonologicznymi i wprowadzić w światowy 
dyskurs naukowy polskie osiągnięcia, zwłaszcza w obszarze badań medycznych i chemicznych. Niestety, rodzime piśmiennictwo z zakresu syndonologii z drugiej połowy XX w. ma charakter w dużej mierze przyczynkarski, informacyjno-popularyzatorski, dewocyjny i tylko sporadycznie naukowo-popularny. Nigdy natomiast polscy badacze nie byli dopuszczeni do udziału w badaniach prymarnych, zastrzeżonych tylko dla nielicznej grupy uczonych, którym władze kościelne pozwalały na prowadzenie prac empirycznych nad próbkami pobranymi z całunu.

Ostatnie lata XX i pierwsze dekady XXI w. przyniosły w obszarze polskiej syndonologii wiele nowości. Pojawiły się w dość dużej liczbie (ok. 60 druków zwartych - zob. bibliografia) tłumaczenia obcej literatury syndonologicznej różnego gatunku (popularno-naukowej, dewocyjnej, tzw. śledczej, beletrystycznej, sprawozdawczej, rzadziej naukowo-popularnej), najczęściej włoskiej proweniencji. Odchodzącą nieliczną pierwszą grupę powojennych polskich syndonologów zastąpiła nowa, do której należą (wymienię tylko tych, którzy mają status akademicki) profesorowie: Jan S. Jaworski, ${ }^{24}$ Władysław Sinkiewicz, Wojciech Kucewicz, Wojciech Zając, Wojciech Szaraniec, Idzi Panic, Zbigniew Treppa, o. Andrzej Napiórkowski, ks. Roman Bogacz. Do niej należałoby dodać popularyzatorów wiedzy o całunie takich jak: Jerzy Górny, Janusz Rosikon, Andrzej Datko, Krzysztof Tarnowski i Alfred Palla (zob. bibliografia sub verbo).

To wszystko składa się na nową jakość w polskiej syndonologii. Otrzymała ona instytucjonalne wsparcie dzięki zorganizowaniu

24 Znany polski uczony, m.in. profesor Uniwersytetu Warszawskiego i wieloletni kierownik Laboratorium Elektrochemii Organicznej. Już w latach osiemdziesiątych XX w. opublikował dwa artykuły o całunie: J. S. J a w o r s k i, Wyniki ostatnich badań Całunu Turyńskiego, Przegląd Powszechny 7-8/1983, s. 109-119; t e n ż e, Indentyfikacja monet z Całunu Turyńskiego, Przegląd Powszechny 2/1985, s. 292-294. Następnie, ale to już XXI w., był współorganizatorem międzynarodowej interdyscyplinarnej konferencji „Toruń Acheiropoietos Conference 2011”, zob. http://www.acheiropoietos.umk.pl/organizatorzy.php (dostęp: 26 I 2018), na której wygłosił referat pt. Chemical aspects of acheiropoietos images. Niestety, materiały $\mathrm{z}$ tej konferencji nie zostały do tej pory opublikowane. 
w 2012 r., przez Zgromadzenie Księży Legionistów Chrystusa we współpracy z Fundacją „Othonia”, stałej wystawy w krakowskim Centrum Jana Pawła II pt. Kim jest Człowiek z Całunu?, która prezentuje historię całunu turyńskiego, wyniki prowadzonych nad nim badań naukowych oraz jego koherencję z przekazami ewangelicznymi. Po pięciu latach od tego wydarzenia zorganizowano pierwszy w Polsce Dzień Całunu (21 X 2017), który z założenia ma się wpisać na stałe do polskiego kalendarza, i powołano do istnienia Polskie Centrum Syndonologiczne. ${ }^{25}$ Jego celem jest prowadzenie badań naukowych nad całunem w koordynacji z innymi zagranicznymi ośrodkami, zwłaszcza Międzynarodowym Centrum Syndonologicznym w Turynie, ich popularyzacja oraz edukacja religijna, mająca źródło w całunie turyńskim. Jego powstanie oraz zadeklarowany udział w nim większości syndonologów z drugiego pokolenia powojennego obiecuje wzmożenie polskiej aktywności w obszarze syndonologii oraz planowe i systematyczne rozwijanie, wciąż mało w Polsce znanej, nowej dyscypliny naukowej.

Krzysztof PILARCZYK

Słowa kluczowe: całun turyński, syndonologia, historia chrześcijaństwa, relikwie

Keywords: Turin shroud, syndonology, history of Christianity, relics

\section{Polish syndonologists. From the history of research of the Turin Shroud and their popularization \\ Summary}

The establishment of the Polish Center of Syndonology in Krakow in 2017, which is the delegation of the International Center of Syndonology in Turin, inspired the author to reflect on the Polish research on the Shroud of Turin. The article presents three generations of Polish syndonologists: (1) the few knowledge about the shroud who popularized up to 1939, (2) five

25 Jego aktywność dokumentowana jest na stronie http://calun.info/pcs/. 
major investigators of the shroud from the second half of the twentieth century and co-founders of the Syndonological Study in Krakow, created at the Polish Theological Society in 1981, and (3) the shroud researchers in the 21st century cooperating with the Polish Center of Syndonology. Their main research and educational achievements as well as participation in international fora were pointed out. The article is supplemented by Polish syndonological bibliography.

\title{
ANEKS \\ POLSKA BIBLIOGRAFIA SYNDONOLOGICZNA
}

\author{
oprac. Krzysztof Pilarczyk*
}

\section{Publikacje zwarte}

\section{Polskiej proweniencji}

Alexiewicz Tomasz, Kozieł Stanisław: Rekolekcje z Całunem Turyńskim. Kontemplacja Całunu Turyńskiego, Inicjatywa Wydawnicza „Jerozolima" Łukasz Kałużny, Poznań 2009, ss. 79.

Aszyk Karolina, Treppa Zbigniew: The Manoppello Icon the prototype of images of Christi, Wydawnictwo Uniwersytetu Gdańskiego, Gdańsk 2014, ss. 91, il.

Aszyk Karolina, Treppa Zbigniew: Ikona z Manoppello prototypem wizerunków Chrystusa, Wydawnictwo Uniwersytetu Gdańskiego, Gdańsk 2015, ss. 94, il.

Datko Andrzej: Księga relikwii, Wydawnictwo M, Kraków 2014, ss. 418.

Górny Grzegorz, Rosikoń Janusz: Świadkowie tajemnicy. Śledztwo w sprawie relikwii Chrystusowych, Rosikon Press, Warszawa 2012, ss. 335, il.

* Wyrażam podziękowanie ks. dr. hab. Piotrowi Ostańskiemu za udostępnienie bibliograficznej bazy danych z zakresu biblistyki polskiej (1945-2015), w której są również notowane publikacje syndonologiczne, co pozwoliło zweryfikować i uzupełnić opracowany spis polskich syndonianów. Jednocześnie podzielam uwagę zwróconą mi przez mgr. Oskara Kopczyńskiego dotyczącą braku w niniejszym zestawieniu netografii. Dziękuję mu za wnikliwą lekturę artykułu (preprintu) i dostrzeżone w nim błędy, które w wersji do druku zostały poprawione. 
Hermanowicz Andrzej: Mistyczne podróże, wstęp Lech Majewski, Księgarnia św. Jacka; Stowarzyszenie Angelus Silesium, Katowice 2005, Ss. 152, il.

Jezus Chrystus. Tajemnica Całunu, GM Records [Warszawa 2006], płyta VCD.

Kłopotowski Mieczysław: Całun Turyński, Instytut Wydawniczy Pax, Warszawa 1984, ss. 30, 36 przeźroczy.

Konikiewicz Leonard W.: Całun Turyński ws świetle nauki. Najnowsze badania autora potwierdzaja autentyczność Całunu. Cyfrowe wzmocnienie potwierdzajace autentyczność tkaniny, Panorama Publishing Co, Chicago 1999, ss. 76; tabl.: fot. kolor.

Leonhard Bolesław: Lekarz wobec Całunu Turyńskiego. (Polemika), Wydawnictwo „Skauta”, Kraków 2008, ss. 16, il.

Ładzina Wanda: Ziemska postać umęczonego Chrystusa wedtug Całunu Turyńskiego, Wiek Nowy, Warszawa [1939], s. 70, [2], il.

Marecki Józef, Rotter Lucyna: Relikwie - leksykon, historia, cuda, kult, eSPe, Kraków 2012, ss. 200, il.

Pakuła Justyna: Męka Chrystusa na podstawie Całunu Turyńskiego wobec wizji Marii z Agredy, bt. Katarzyny Emmerich, Marii Valtorty, Michalineum, Marki 2010, ss. 96.

Palla Alfred Jan: Całun Turyński jednak autentykiem w świetle nowych odkryć i badań, Betezda, Rybnik 2003, ss. 192, il., fot.

Palla Alfred Jan: Całun Turyński. Wielka historia czy wielka mistyfikacja, wyd. 2 popr. i rozszerz., Świat Książki - Bertelsmann Media, Warszawa 2008, ss. 198, [16] s. tabl., il.

Rec.: Blaza Marek: Apologia całunu, „Przegląd Powszechny” 125(2009) nr 5.

Panic Idzi: Tajemnica Całunu, Wydawnictwo AVALON T. Janowski, Kraków 2010, ss. 308, il.

Paterek Anna: Najcenniejsze relikwie chrześcijaństwa, Arystoteles, Warszawa 2016, ss. 60, il.

Polewska Aleksandra: Piątek, który zmienit wszystko. Męka Pańska w'świetle zdumiewajacych odkryć i niezwyktych wizji mistycznych, Rafael, Kraków 2013, ss. 236, il.

Polewska Aleksandra: Wielkie relikwie chrześcijaństwa, Rafael, Kraków 2012, ss. 264, il.

Prószyński Kazimierz: Niestychane odkrycie naukowe. Prawdziwa fotografja Pana Jezusa i ślady całej męki Jego na całunie, oprac. na 
podstawie źródeł naukowych..., Druk F. Wyszyński, Warszawa 1932, ss. 15. Praca drukowana była częściowo w „Gazecie Świątecznej”. Toż po ang.: Lonon 1933. Rec.: „Wolnomyśliciel Polski” 8/1935 s. 111. Pyszkowski Wacław: Święty Całun jako fenomen naukowy, historyczny i religijny [Zryw, Bydgoszcz 1946], ss. 29, [1], 7 tabl.

Rec.: Wib.: Wizerunek Chrystusa, „Słowo Powszechne” 1(1947) nr 57 s. 3. Sadło Krzysztof: Rozważanie Drogi Krzyżowej wedlug Całunu Turyńskiego, Wydawnictwo M, Kraków 2014, ss. 77, il.

Spiss Maria: Świadkowie calunu, Wydawnictwo M, Kraków 2004, ss. 110. Szefer Sylwester (red.), Tajemnica Całunu Turyńskiego, Wydawnictwo AA, Kraków 2008, ss. 93, il. (Biblioteka „Jezus Żyje”).

Tarnowski Krzysztof: Całun Turyński jest prawdziwy. „Zmartwychwstanie relikwii Chrystusa", Krzysztof Tarnowski, Warszawa 2001, ss. 366, il.

Tarnowski Krzysztof: Całun Turyński. Relikwia czy genialne fatszerstwo? Instytut Wydawniczy Pax, Warszawa 2011, ss. 210, il.

Treppa Zbigniew: Całun Turyński. Fotografia Niewidzialnego? Wydawnictwo Więź, Warszawa-Gdańsk 2004, ss. 148, il.

Treppa Zbigniew: Fotografia z Manoppello. Twarz Zmartwychwstatego Mesjasza, Wydawnictwo Duszpasterstwa Rolników, Włocławek [2009], ss. 349, il.

Treppa Zbigniew: Obraz jako medium wtajemniczajace w misterium na przykładzie obrazów nie-rękq-ludzka-wykonanych i pochodzacych $z$ wizji mistycznych, Wydawnictwo Uniwersytetu Gdańskiego, Gdańsk 2017, ss. 178.

Tycner-Wolicka Marta: Opowieść o wizerunku z Edessy. Cesarz Konstantyn Porfirogeneta i nieuczyniony ręka wizerunek Chrystusa, Avalon, Kraków 2009, ss. 232, il.

Waliszewski Stanisław: Całun turyński dzisiaj, WAM, Kraków 1987, ss. 171, [40] s. tabl., fot., il.

Toż: wyd. 2, 1988; wyd. 3, powiększ. 1994, ss. 214.

Ziółkowski Zenon, Całun Turyński. Milczacy świadek męki, śmierci i zmartwychwstania, Oficyna Adam, Warszawa 2011, ss. 224.

Ziółkowski Zenon: Spór o Całun Turyński. Relikwia Męki Pańskiej w świetle najnowszych badań naukowych, Oficyna Adam, Warszawa 1994, ss. 190, [16] s. tabl., fot., il.

Toż: 1996. 


\section{Autorów zagranicznych}

Accorneo Pier Giuseppe: Catun. Historia, nauka, kult, thum. Krystyna Kozak, Wydawnictwo Jedność, Kielce 2017, ss. 255.

Antonacci Mark: Zmartwychwstanie Catunu. Przetom w badaniach Catunu Turyńskiego. Najnowsze wyniki potwierdzaja jego autentyczność, tłum. Agnieszka Kowalska, Amber, Warszawa 2002, ss. 319, il. (Tajemnice Przeszłości).

Badde Paul: Twarza w Twarz. Świadkowie koronni zmartwychwstania, thum. Jolanta Mączka, Wydawnictwo Niecałe, Bytom/ „Gość Niedzielny” Katowice 2013, ss. 200, il.

Baima Bollone Pierluigi: Catun Turyński. 101 pytań i odpowiedzi, thum. Krzysztof Stopa, WAM, Kraków 2002, ss. 287.

Fragm.: Znak, który doczekat aż do naszych czasów, „List” 23(2006) nr 4, s. 24.

Baima Bollone Pierluigi, Zaca Stefano: Catun pod mikroskopem. Analiza medyczno-sadowa, tłum. Alicja Lis, Wydawnictwo Salezjańskie, Warszawa 1998, ss. 32, il. (Całun Turyński, 2).

Balon Marek: Cudowne wizerunki Chrystusa, Dom Wydawniczy Rafael, Kraków 2017, ss. 128.

Balossino Nello: Wizerunek na Całunie. Analiza fotograficzna i informatyczna, tłum. Alicja Lis, Wydawnictwo Salezjańskie, Warszawa 1998, ss. 48, il. (Całun Turyński, 5).

Barberis Bruno [i in.], Autopsja Człowieka z Całunu. Najnowsze odkrycia tajemnic Całunu Turyńskiego, autorzy: Bruno Barberis, Luigi Fabrizio Rodella, Giovanni Pierucci, Mauro Labanca, Alessandra Majorana, Giampier Farronato, Massimo Boccaletti, Dom Wydawniczy Rafael, Kraków 2017, ss. 144.

Barberis Bruno, Bocalletti Massimo: Całun. Śledztwo w sprawie Ukrzyżowanego, tłum. Paweł Soppa, Instytut Wydawniczy Pax, Warszawa 2010, ss. 31, il.

Toż: Edycja Św. Pawła, Częstochowa 2010.

Barberis Bruno, Boccaletti Massimo: Całun. Kwestia wciaż otwarta, thum. Arkadiusz Soćko, Jedność, Kielce 2011, ss. 295, [1] k. tabl. luzem; il.

Barberis Bruno, Savarino Piero: Wiek Całunu. Badania izotopem węgla C-14 oraz rachunek prawdopodobieństwa, thum. Alicja Lis, Wydawnictwo Salezjańskie, Warszawa 1998, ss. 48, il. (Całun Turyński, 6). 
Bennett Janice: Święta chusta, święta krew. Tajemnica Sudarionu z Oviedo, nieznanej relikwii Grobu Pańskiego, tłum. Piotr Zarębski, Fides et Traditio, Rzeszów/ Wydawnictwo AA, Kraków 2011, ss. 372, il., faks., fot.

Całun. Tajemnica świętego płótna. [Film], prod. Cinestudio 80 - Sampaolofilm; oprac. M. Damato, M. Branchesi, G. Giordano, $27 \mathrm{~min}$. (Dokumenty).

Całun. Tajemnice ptótna z Turynu, reż. Dawid Rolfe, E-lite Distribution, Warszawa [2015], DVD (50 min.) (Ekskluzywna Kolekcja Ludzie Boga Fakty, Cuda, Tajemnice, t. 4).

Całun Turyński, reż. Doug Campbell; scenariusz Brian Russell, Charles E. Sellier, Hagi Film i Video, Wrocław 1994, 30 min. (Filmoteka Chrześcijańska).

Centini Massimo: Ślady Boga. Dzieje Chrystusa zapisane w Jego relikwiach, tłum. Paweł Borkowski, Instytut Wydawniczy Pax, Warszawa 2016, ss. 200.

Centini Massimo: W poszukiwaniu Weroniki. Pasjonujaca opowieść o relikwiach oblicza Chrystusa, tłum. Joanna Curyło, Dom Wydawniczy Rafael, Kraków 2008, ss. 222, [16] s. tabl.: il.

Christer Sam: Tajemnica Całunu Turyńskiego, tłum. Paweł Cichawa, Wydawnictwo Sonia Draga, Katowice 2014, ss. 404, il.

Cormack Robin: Malowanie duszy. Ikony, maski pośmiertne i całuny, tłum. Krzysztof Kwaśniewicz, Kraków 1999, ss. 270, il.

Fanti Giulio, Gaeta Saverio: Tajemnica Całunu. Zdumiewajace odkrycia nauki w kwestii Całunu Turyńskiego, tłum. Marcin Masny, Wydawnictwo Św. Stanisława BM, Kraków 2015, ss. 212, il.

Favaro Oreste: Droga krzyżowa z całunem, tłum. Jolanta Morytz, Wydawnictwo Salezjańskie, Warszawa 1997, ss. 31.

Frale Barbara: Całun Jezusa Nazarejczyka, tłum. Grzegorz Rawski, WAM, Kraków 2012, ss. 462, [16] s. tabl.: il.

Frale Barbara: Templariusze i Całun Turyński, tłum. Grzegorz Rawski, Wydawnictwo Apostolstwa Modlitwy, Warszawa 2009, ss. 284, [16] s. tabl.: il.

Toż: wyd. 2, 2011.

Gaeta Savierio: Drugi Całun [chusta Weroniki]. Prawdziwa historia oblicza Jezusa, tłum. Władysław Lisowski, Polwen - Polskie Wydawnictwo Encyklopedyczne, Radom 2007, ss. 172, [16], tabl., il. 
Gardiner Philip: Trzy świętości. Wspólny sekret Arki Przymierza, Catunu Turyńskiego i Marii z Nazaretu, tłum. Przemysław Bieliński, Wydawnictwo Amber, Warszawa 2007, ss. 246, il.

Ghiberti Guseppe: Catun, Ewangelia i życie chrześcijańskie, tłum. Alicja Lis, Wydawnictwo Salezjańskie, Warszawa 1998, ss. 32 (Całun Turyński, 1).

Ghiberti Guseppe: Przed Całunem, tłum. Bernadeta Tomaszek, Edycja Św. Pawła, Częstochowa 2011, ss. 63, il.

Hesemann Michael: Chusta Chrystusa. Naukowcy na tropie zmartwychwstania, tłum. Emilia Skowrońska, Wydawnictwo Św. Stanisława BM, Kraków 2014, ss. 310, [16] s. tabl. il.

Hesemann Michael: Milczacy świadkowie Golgoty. Fascynujaca historia relikwii Chrystusowych, tłum. Katarzyna Zimmerer, Wydawnictwo Salwator, Kraków 2006, ss. 398, il.

Hynek Rudolf Waldorf: Święty Całun z Turynu. Męka Pańska w oświetleniu nauki, spolszczył i oprac. Stanisław Karwowski, Księgarnia Św. Wojciecha, Poznań 1937, IX, [1], 127 s., 8 k. tabl.

Wyd. 2, 1938, VIII, 141, 10 k. tabl.

Rec.: Bross Kazimierz: Święty Catun, „Kultura” 2(1937) nr 17, s. 7; Dajczak Józef: „Gazeta Kościelna” 44/1937, s. 170-171; Dobraczyński Jan: Dokument z pewnego procesu, „Kultura” 4(1939) nr 14/15, s. 8.

Kersten Holger, Gruber Elmar R.: Jezus ofiara spisku. Prawda o zmartwychwstaniu, tłum. S. Lisiecka, Uraeus, Gdynia 1995, ss. 392.

Rec.: Hoffmann Henryk: Calun Turyński-falsyfikat czy mistyfikacja? „Nomos” 14/1996, s. 144-149.

Knight Christopher: Drugi Mesjasz. Templariusze. Całun Turyński i wielkie tajemnice masonerii, tłum. Jerzy Korpanty, Orpheus, Warszawa 1998, ss. 279, [16] s. tabl.: il.

Manera Massimiliano: Święty Całun. Przenikanie się historii, nauki wiary, nadziei, tłum. Krzysztof Stopa, „Bernardinum”, Pelplin 2015, ss. 28.

Marinelli Emanuela: Całun. Obraz ,niemożliwy”? tłum. Waldemar Polczyk, Wydawnictwo św. Antoniego, Wrocław 1999, ss. 160, [14] k. tabl.: il.

Marion André, Courage Anne-Laure: Całun Turyński. Nowe odkrycia nauki, tłum. Piotr Murzański, Znak, Kraków 1999, ss. 244, il.

Toż: wyd. 2, 2000, ss. 343, [12] s. tabl.: il.

Marion André, Lucotte Gérard: Tunika z Argenteuil i Całun Turyński. Podsumowanie badań, tłum. Anna Łatka, Wydawnictwo „M”, Kraków 2008, ss. 254, [16] s. tabl.: il. 
Martini Carlo Maria: Bóg ukryty. Medytacje o Całunie, tłum. Juliusz Zychowicz, Wydawnictwo Apostolstwa Modlitwy, Kraków 2013, ss. 78.

Meacham William: Spisek przeciwko Catunowi. Jak błędnie potępiono i zbezczeszczono najcenniejsza chrześcijańska relikwię, tłum. Jan J. Franczak, Wydawnictwo AA, Kraków 2015, ss. 512.

Milanesio Antonio, Siracusa Simona, Zaca Stefano: Tajemniczy „Wizerunek". Hipotezy na temat powstania wizerunku na Catunie, tłum. Alicja Lis, Wydawnictwo Salezjańskie, Warszawa 1998, ss. 40, il. (Całun Turyński, 4).

Moretto Gino: Całun. Przewodnik, tłum. Alicja Lis, Wydawnictwo Salezjańskie, Warszawa 1998, ss. 80, il.

Navarro Julia: Bractwo świętego całunu, tłum. Agnieszka Mazuś, Świat Książki, Warszawa 2007, ss. 447.

Nickell Joe: Całun Turyński, tłum. Bogusława Warchołowicz, Pandora, Łódź 1996, ss. 248.

Odwieczne tajemnice świata, reż. Doug Campbell; prod. Allan C. Pedersen, Best Film, Warszawa 1995, kaseta VHS (96 min.).

Na podstawie książki Charles E. Selliera.

Odwieczne tajemnice świata, reż. Doug Campbell; prod. Allan C. Pedersen, Hagi Film, Wrocław 1995, kaseta VHS (100 min.).

Na podstawie książki Charles E. Selliera.

Petrosillo Orazio, Marinelli Emanuela: Całun Turyński. Relikwia czy falsyfikat. Krytyka ostatniego datowania, tłum. Zenon Ziółkowski, Wydawnictwo Księży Marianów, Warszawa 1993, ss. 283, il.

Resch Andreas: Oblicze Chrystusa. Od Całunu Turyńskiego do Chusty z Manoppello. 128 fotografii, w tym 14 barwnych tablic, tłum. Artur Kuć, Polskie Wydawnictwo Encyklopedyczne, Radom 2006, ss. 146, il. Ricci Giulio: L'Uomo della della Sindone é Gésu, Roma-Porziuncola-Assisi 1969, ss. 477.

Rec.: Pieńkowska Barbara: Człowiekiem z całunu jest Jezusa, „Tygodnik Powszechny” 29(1975) nr 12, s. 1, 4-5, il.; r.: Całun, „Myśl Społeczna” 33/1978, s. 10; Rusinek Maria: Autentyczność Całunu Turyńskiego? Najnowsze badania ks. Giulio Ricci, „Słowo Powszechne” 31(1977) nr 179, s. 7, il.; W. M.: „Homo Dei” 41(1972) nr 3, s. 234.

Sbalchiero Patrick: [Dwanaście] 12 tajemnic chrześcijaństwa, które rzucity wyzwanie nauce, tłum. Anna Kocot, Wydawnictwo Esprit, Kraków 2016, ss. 272, il. 
Scannerini Silvano: Mirra, aloes, pyłki i inne ślady. Analiza botaniczna, tłum. Alicja Lis, Wydawnictwo Salezjańskie, Warszawa 1998, ss. 64. (Całun Turyński, 7).

Schiatti Lamberto: Całun Turyński. Mały przewodnik, tłum. Krystyna Kozak, Edycja Świętego Pawła, Częstochowa 2003, ss. 59, il.

Schiatti Lamberto: Całun Turyński. Przewodnik po obrazie pełnym tajemnic, tł. z wł. Paweł Soppa, Częstochowa: Edycja Świętego Pawła 2000, ss. 31, il., fot.

Schloemer Blandina Paschalis: Jezus Chrystus - świadectwo Jego całunów, tł. Barbara Rysiewicz, Radom: Polwen 2009, ss. 218, il.

Schwortz Barrie: Oblicze prawdy. Żyd, który zbadat Catun Turyński, rozm. przepr. Grzegorz Górny; tłum. James Savage-Hanford, Mirosław Gąda, Rosikon Press, Izabelin-Warszawa 2013, ss. 144, il. (Świadkowie Tajemnicy).

Sennott Thomas Mary: Nie uczynione ludzkimi dtońmi. O cudownym wizerunku Matki Boskiej z Guadelupy i Całunie Turyńskim, tłum. Agnieszka Zięba; wprowadzenie Petrer Mary Fehler, Wydawnictwo Diecezjalne i Drukarnia, Sandomierz 2006, ss. 147, il.

Siliato Maria Grazia: Całun. Tajemnica odbicia postaci sprzed dwóch tysięcy lat, tłum. Hanna Bzikot, Wydawnictwo M, Kraków 1997, ss. 309, il.

Socci Antonio: Śledztwo w sprawie Jezusa, thum. Katarzyna Kubis, Rafael, Kraków 2010, ss. 328, il.

Sora Steven: Skarby z niebios. Dzieje legendarnych, prawdziwych i fatszywych relikwii chrześcijaństwa, tłum. Ewa Witecka, Amber, Warszawa 2005, ss. 221, il.

Tornielli Andrea: Śledztwo w sprawie Całunu, tłum. Lucyna Rodziewicz-Doktór, Wydawnictwo AA, Kraków 2011, ss. 153.

Tornielli Andrea: Zmartwychwstanie. Tajemnice, legendy i prawda. Od Ewangelii do Kodu Leonarda da Vinci, tłum. Lucyna Rodziewicz-Doktór, eSPe, Kraków 2007, ss. 248, il.

Wilson Ian: Całun Turyński, tłum. Jadwiga Piątkowska, Wydawnictwo Apostolstwa Modlitwy, Kraków 1978, ss. 279, tabl.

Toż: Kuria Metropolitalna, Kraków 1983. ss. 279, [40], il.

Toż: tłum. i posłowie Andrzej Polkowski; bibliografia polska Zenon Ziółkowski, Instytut Wydawniczy Pax, Warszawa 1983, ss. 348, il. Wyd. 2, Instytut Wydawniczy Pax, Warszawa 1984, ss. 367, [32] s. tabl.: faks., il. 
Toż: tłum. Władysław Fenrych, Krystyna Karwowska, Ewa Waliszewska, Księgarnia św. Wojciecha, Poznań 1984, ss. 222, 16 tabl. Wyd. 2, Kraków: WAM 1984, ss. 279. Wyd. 3, 1985.

Toż: t. 1-2, tłum. i posłowie Andrzej Polkowski [b.m.w. 1986?] ss. 3-144, 145-347.

Rec.: Karcz Jan: Całun Turyński. Świadek męki i zmartwychwstania, „Za i Przeciw” 1984 nr 14, s. 6-7, 23, il.; Skwarnicki Marek: Pobożny bestseller, „Tygodnik Powszechny” 38(1984) nr 22, s. 8; Zguba Jan, „Ład” 4(1984) nr 16; Ziółkowski Zenon: „Całun Turyński” I. Wilsona, „Życie i Myśl” 33(1984) nr 3, s. 102-105; Ziółkowski Zenon: Książka Roku Odkupienia, „Kierunki” 29(1984) nr 4, s. 4.

Wilson Ian: Krew i Całun, tłum. Bogdan Mizia, Amber, Warszawa 1999, ss. 288, [56] s. tabl. (Tajemnice Przeszłości).

Wilson Ian: Święte oblicza. Poszukiwanie prawdziwego wizerunku Chrystusa, tłum. Marek Fedyszak, Da Capo, Warszawa 1994, ss. 319, il.

Wilson Ian: The Turin Shroud, Victor Gollanez Ltd., London 1978, ss. XIV, 272, 40 s., il.

Rec.: Kaznowski Zbigniew, „Ruch Biblijny i Liturgiczny” 34(1981) nr 3, s. 186-187.

Zaccone Gian Maria: Catun Turyński. Historia tajemnicy, tłum. Dominika Wronikowska, eSPe, Kraków 2011, ss. 328, il.

Zaccone Gian Maria: Śladami Całunu. Historia dawna i współczesna, tłum. Alicja Lis, Wydawnictwo Salezjańskie, Warszawa 1998, ss. 64, il. (Całun Turyński, 3).

Zurdo David: Ostatnia tajemnica Leonadra da Vinci, tłum. Ewa Morycińska-Dzius, Wydawnictwo Amber, Warszawa 2005, ss. 239.

Toż: wyd. 2, 2005.

\section{Druki niesamoistne}

Polskiej proweniencji

A.M.: Jeszcze o Całunie z Turynu, „Za i Przeciw” 12(1968) nr 41, s. 7. Adamczyk R.: Całun Turyński w świetle badań naukowych, „Apostolstwo Chorych" [Katowice] 49(1978) nr 5, 7 s. [nienumerowane], il. Adamczyk-Aiello Alina: Całun, „Kierunki” 26(1980) nr 32, s. 4, il. (AP): Nowe stwierdzenia w sprawie Catunu Turyńskiego, „Słowo Powszechne" 34(1980) nr 150, s. 2. 
Autentyczność Całunu Turyńskiego, „Tygodnik Powszechny”27(1973) nr 12, s. 7.

Banak Jerzy, Catun Turyński, „Zorza” 22(1978) nr 35, s. 12-13, il.

Banak Jerzy, Kalendarium Catunu Turyńskiego, cz. 1-2, „Zorza” 22/1978; cz. 1: Dzieje Całunu na Wschodzie, nr 39, s. 12-13, i1.; cz. 2: Dzieje Catunu na Zachodzie, $\mathrm{nr} 41$ s. 7, il.

Bednarczyk M.: Tajemniczy ,portret”. Czy Całun Turyński okrywat ciało Chrystusa? „Sztandar” 1992 z dn. 17-20 IV, . s. 5, il.

Bem Henryk, Domański Tomisław: Niektóre aspekty datowania Całunu Turyńskiego technika akceleratorowej spektometrii masowej (AMS), „Prace i Materiały Muzeum Archeologicznego i Etnograficznego w Łodzi. Seria Numizmatyczna i Konserwatorska" 11/1996, s. 205-210.

Bieniek J.: Zobacz Catun! Czy okrywat umęczone ciało Chrystusa? „Viva” 10/1998, s. 22-26, il.

Bochenek Małgorzata: „Nie dla ekonomii odrzucenia, „Nasz Dziennik” (wyd. 2) 134/2015, s. 10.

Borowicz Kazimierz: Obraz Chrystusa na t.zw. Świętym Całunie z Turynu, „Ruch Biblijny i Liturgiczny” 1(1948) nr 5-6, s. 287-305.

Brandstaetter Roman: Hymn o Catunie Turyńskim, „W Drodze” 12(1984) nr 4, s. 3-6.

Toż: „Ład Boży” 7/1985, s. 4; „Nasza Rodzina” 4/1986, s. 10-11.

Bujak Janusz: Ekumeniczne znaczenie Całunu Turyńskiego, „Scripturae Lumen. Biblia i Jej Oddziaływanie" 7/2015, s. 379-397.

(BUR): Catun z Turynu: 1578-1978, „Za i Przeciw” 12/1978, s. 10.

(BUR): Jeszcze o „Catunie Turyńskim”, „Za i Przeciw” 18/1977, s. 10.

(BUR): Pierwsze konkluzje dotyczace Całunu Turyńskiego, „Za i Przeciw” 4/1979, s. 10.

(C): Temat-Całun Turyński [sympozjum w Londynie], „Gość Niedzielny 54" 43/1977, s. 344.

Caban Bernard Krzysztof: Autentyczne odbicie Chrystusa, „Słowo Powszechne" 7(1953) nr 44, s. 3, il.

Całun turyński-świadek zmartwychwstania? Catun z Manoppello-prawdziwe oblicze Chrystusa? red. Grzegorz Polak, „Gazeta Wyborcza” 98/2010 (dodatek „Tajemnice Chrześcijaństwa. Cuda. Objawienia. Proroctwa" nr 1), s. 1-15.

Całun Turyński, „WTK” 8(1960) nr 15, s. 2.

Toż: „Gość Niedzielny 58(1981) nr 26, s. 7. 
Chmiel Jerzy: Całun Turyński Anno Domini 1998, „Ruch Biblijny i Liturgiczny" 51(1998) nr 1, s. 47-50.

Chmiel Jerzy: Całun Turyński znakiem męki i zmartwychwstania Jezusa? „Tygodnik Powszechny” 34(1980) nr 15, s. 3, 7.

Chmiel Jerzy: Jan Pawet II i Całun Turyński, w: Stefan Koperek, Stanisław Szczur (red.), Servo veritatis. Materiaty międzynarodowej konferencji dla uczczenia 25-lecia pontyfikatu Jego Światobliwości Jana Pawła II, Uniwersytet Jagielloński, 9-11 października 2003 r., Wydawnictwo Naukowe Papieskiej Akademii Teologicznej, Kraków 2003, s. 763-766.

Chmiel Jerzy: La semiotica della Sindone di Torino, w: Worldwide Congress „Sindone 2000”. Proceedings of the Congress, Orvieto, August 27-29, 2000 [CD-Rom].

Chmiel Jerzy: Polskie badania nad Catunem Turyńskim, „Tygodnik Powszechny" 38(1984) nr 16, s. 7.

Chmiel Jerzy: „Szukam, o Panie Twojego oblicza” (Ps 27,8). Refleksja syndonologiczna, „Ruch Biblijny i Liturgiczny” 52(1999) nr 1, s. 49-50. Toż: , Jezus Żyje” [Mogilany].

Chmiel Jerzy: 15-lecie istnienia Studium Syndonologicznego, „Ruch Biblijny i Liturgiczny" 49(1996) nr 3, s. 201-206.

Chmiel Jerzy: Tajemnica całunu, „Przekrój” 15/1998, s. 9-11, il.

Chmiel Jerzy: Wokót Całunu turyńskiego, „Źródło” 1992 nr 33 z dn. 18 VIII, s. 10.

Choczyńska Irena: Chemiczne datowanie Całunu Turyńskiego, „Wszechświat" 113(2012) nr 7-9, s. 185-190.

Chrostowski Waldemar: Calun przyjąt Jezusa martwego, a oddat Go żywego, „Nasz Dziennik” 2010 nr 101 z dn. 30 IV - 3 V 2010, s. 24-25, fot.

Chrystofor Jan: Święty Całun z Turynu. Męka Pańska w oświetleniu nauki, „Niedziela” 15/ 1945, s. 102-103.

(CIS): Catun Turyński wystawiony, „Za i Przeciw” 3/1978, s. 10.

(CIS): Ekspertyza szwajcarska dotyczaca Catunu, „Za i Przeciw” 20/1981, s. 10.

(CIS): Jeszcze o Całunie Turyńskim, „Za i Przeciw” 6/1984, s. 10.

Co mówi Catun? „List” 23(2006) nr 4, s. 20-23, fot.

Cymer Adam: Milczacy świadek [Całun Turyński], „Myśl Społeczna” 38/1978, s. 4, 9, il.

Czarnecka Katarzyna: Catun Turyński a archeologia, „Przegląd Powszechny” 248(1985) nr 9, s. 396-398. 
Czarniecki Stefan: Spojrzenie, które zmienia, „Nowa Gazeta Praska” 8/2014, s. $80-85$.

Czerwiński A.: Te wyniki to dopiero początek, „Słowo Powszechne” 43(1989) nr 2, s. 9.

Czytelnik ,Wolnomyśliciela”: w sprawie całunowej fotografii, „Wolnomyśliciel Polski" 8/ 1935, s. 190.

Dąbrowski Eugeniusz: Sprawa Całunu Turyńskiego, „Znak” 5(1950) nr 25, s. 309-321.

Rec.: Weiss-Dąbska W.: List do redakcji, „Znak” 5/1950, s. 455-456; Gołubiew Antoni: Jeszcze o sprawie Catunu Turyńskiego, „Znak” 6(1951) nr 28, s. 181-183.

Dąbrowski Eugeniusz: Sprawa Całunu Turyńskiego, Studia biblijne, Instytut Wydawniczy Pax, Warszawa 1951, s. 185-202.

Toż: wyd. 2, 1952, s. 171-187.

Dąbrowski J.: Czym jest naprawdę Całun turyński? „Świat Młodych” 46/1981, s. 5, il.

Decyzja w sprawie św. Całunu [przechowywania go nadal w Turynie], „Myśl Społeczna” 4/1984, s. 8.

Derelkowska E.: Catun Turyński-relikwia niezwykła, „Rodzina” 20/1985, s. 3, il.

Dobraczyński Jan: Całun Turyński, „WTK” 4(1956) nr 25, s. 9-10, il. Toż: „Tygodnik Katolicki” 1(1956) nr 4, s. 9-10, il.

Dobraczyński Jan: Piąta Ewangelia, „Słowo Powszechne” 3(1949) nr 90, s. $1-2$.

Dobraczyński Jan: Sprawa Całunu Turyńskiego, „Dziś i Jutro” 6(1950) nr 3, s. 8.

Dobraczyński Jan: Wciąż tajemniczy catun, w: tenże, Wielkość i świętość. Eseje, Instytut Wydawniczy Pax, Warszawa 1958, s. 49-56.

Dobrzeniecki Tadeusz: Niektóre zagadnienia ikonografii Męża Boleści, „Roczniki Muzeum Narodowego w Warszawie” 15/1971, cz. 1, s. 72-75.

Dołęga-Chodasiewicz Jerzy: Całun Turyński, cz. 1-2, „Nasze Życie” 13(1991) nr 40-41; cz. 1: Rekonstrukcja dziejów Relikwii, nr 40, s. 13-16; cz. 2: Przedmiot badań naukowych, nr 41, s. 36-38.

Dołęga-Chodasiewicz Jerzy: Całun Turyński, nauka i wiara, „Gazeta Starachowicka" 21/1998.

Dołęga-Chodasiewicz Jerzy: Całun Turyński nie popiera hipotezy Korabiewicza, „W Drodze” 21(1993) nr 6, s. 98-99. 
Dołęga-Chodasiewicz Jerzy: Catun Turyński-relikwia i tajemnica, „Najwyższy Czas" 3(1992) nr 16, s. 3-5, 7.

Dołęga-Chodasiewicz Jerzy: Całun Turyński uratowany cudem, „Echo Dnia" [Kielce] 105/1997.

Dołęga-Chodasiewicz Jerzy: Całun Turyński w świetle ostatnich badań, „Przewodnik Katolicki” 74(1986) nr 30, s. 3.

Dołęga-Chodasiewicz Jerzy: Całun Turyński wciąż kusi naukę - nie ręka ludzka wykonany, „Dziennik Zachodni” [Katowice] 90/1998, s. 10.

Dołęga-Chodasiewicz Jerzy: Całun Turyński ,znakiem Jonasza” dla nas, „Nasze Życie” 17(2001) nr 75, s. 3-4.

Dołęga-Chodasiewicz Jerzy: Falsyfikat? Tajemnica Całunu Turyńskiego, „Tygodnik Demokratyczny” 36(1988) nr 52, s. 16-17, il.

Dołęga-Chodasiewicz Jerzy: Historia Całunu Turyńskiego w pierwszym tysiacleciu-najnowsze studia i analiza przekazów źródłowych, w: Waliszewski Stanisław: Całun Turyński dzisiaj, WAM, Kraków 1994, s. 158-166.

Dołęga-Chodasiewicz Jerzy: Jeszcze o artykule „Catun Turyński: Fatszerstwo... badaczy?” „Tygodnik Demokratyczny” 37(1989) nr 51.

Dołęga-Chodasiewicz Jerzy: Kto mnie zobaczyt, zobaczył także Ojca, „Miłujcie" 52/1994, s. 6-7.

Toż: „Kurier Rogoziński” 5(1994) nr 5, s. 15.

Dołęga-Chodasiewicz Jerzy: Ludzkie oblicze Absolutu, „Nasze Życie” 15(1993) nr 52, s. 6-7.

Toż: „Kurier Rogoziński” 5(1994) nr 5, s. 15.

Dołęga-Chodasiewicz Jerzy: Ludzkie Oblicze Boga (J 14,9), „Wstań” 7(1995) nr 1, s. 12-13, il.

Dołęga-Chodasiewicz Jerzy: Niemy świadek śmierci Chrystusa, „Słowo Ludu" [Kielce] 47(1996) nr 161, s. 5.

Dołęga-Chodasiewicz Jerzy: Prawda przeciw domysłom, „Nasze Życie” 15(1993) nr 48, s. 10-12.

Dołęga-Chodasiewicz Jerzy: Świadek. Całun Turyński, „Słowo Ludu” [Magazyn] 2019/1998, s. 12.

Dołęga-Chodasiewicz Jerzy: Świadek męki i zmartwychwstania, „Miłujcie” 3-4/1999, s. 6-10.

Dołęga-Chodasiewicz Jerzy: Trójwymiarowy obraz Całunu, w: Waliszewski Stanisław: Całun Turyński dzisiaj, WAM, Kraków 1987 s. 125-127. Toż: wyd. 2, 1994, s. 125-128. 
Dołęga-Chodasiewicz Jerzy: Ujrzat i uwierzyt, rozm. przepr. Bożena Ulewicz, Zenon Złakowski, „Tygodnik Solidarność” 15/1998, s. 4.

Dołęga-Chodasiewicz Jerzy: W poszukiwaniu nieznanego super geniusza wszystkich czasów, „Niedziela” 40(1997) nr 17, s. 9.

Dołęga-Chodasiewicz Jerzy, Waliszewski Stanisław: Dlaczego Człowieka z Całunu możemy utożsamić z Chrystusem? w: Waliszewski Stanisław: Całun Turyński dzisiaj, WAM, Kraków 1987, s. 100-104.

Toż: Wyd. 3. 1994, s. 100-104.

Dudek Zbigniew: Jednostronicowa Ewangelia, rozm. przepr. Mariusz Książek, „Niedziela” 13/2013, s. 16-19.

E.H.: Czy relikwia z Turynu jest całunem Pana Jezusa, „Myśl Społeczna” 37/1970, s. 8-10, il.

E.S.: Całun Turyński w naszych oczach, „Przewodnik Katolicki” 93(1987) nr 17, s. 6.

Eckmann Augustyn: Milczący świadek, „Orędownik Diecezji Chełmińskiej” 30 (1979) nr 11-12, s. 426-431.

F.D.: Badania nad Całunem Turyńskim, „Rycerz” nr [?]1989, s. 72-73.

Fenrych Władysław: Badania naukowe Całunu Turyńskiego, „Postępy Medycyny Sądowej i Kryminologii” 4/1998, s. 161-172.

Fenrych Władysław: Badania naukowe Całunu Turyńskiego, w: Andrzej Wójtowicz (red.), Biblia w roku 2000. Teksty wykladów wygloszonych na sympozjum naukowym zorganizowanym przez Oddziat Polskiej Akademii Nauk i Wydziat Teologiczny Uniwersytetu im. Adama Mickiewicza w Poznaniu dnia 7 czerwca 2000 roku, Ośrodek Wydawnictw Naukowych, Poznań 2000, s. 61-75, 2 fot.

Fenrych Władysław: Całun Turyński - niezwykła relikwia oraz zabytek archeologiczny, „Ars Senescendii. Zeszyty Uniwersytetu Trzeciego Wieku w Poznaniu" 3/1999, s. 89-95.

Fenrych Władysław: Całun Turyński. Oryginat czy falsyfikat, „Przewodnik Katolicki” 99(1993) nr 40, s. 6.

Fenrych Władysław: Krew na Całunie nie jest zagadka, rozm. z doc. (...), „Za i Przeciw” 29/1984, s. 18-19.

Fenrych Władysław: Modliłem się przy Całunie Turyńskim, „Maryjna Wspólnota" 7-8/1998, s. 2-3, il.

Fenrych Władysław: Próba dziewięciu, w: Waliszewski Stanisław: Całun Turyński dzisiaj, WAM, Kraków 1994, s. 153-157.

Fenrych Władysław: Refleksje z okazji wystawienia Całunu Turyńskiego (18.4.-14.06.1998), „Ruch Biblijny i Liturgiczny” 51(1998) nr 3, s. 215-217. 
Fenrych Władysław: Shroud of Turin - research subjects. Proceedings of the hemp, flax and other bast bibrous plants-production, technology \& ecology symposium. The meeting of the FAO Extraction and Proccesing Working Group. „Włókna Naturalne” 1/1998 [wyd. spec.], s. 13-17, il.

Fenrych Władysław: Świadectwo Całunu o zmartwychwstaniu Chrystusa, w: Waliszewski Stanisław: Całun Turyński dzisiaj, WAM, Kraków 1987, s. $147-150$.

Toż: wyd. 3, 1994.

Fenrych Władysław: Tajemnica Całunu Turyńskiego i Chusty z Oviedo, rozm. Karina Szatkowska, „Sta Allegro” [Poznań], 38/ 1997, s. 2-3.

Fenrych Władysław: [Trzeci] III Międzynarodowy Kongres „Całun a na$u k a ”$, ,Ruch Biblijny i Liturgiczny” 52(1999) nr 1, s. 51-62.

Fenrych Władysław: Wymowne świadectwo śmierci i zmartwychwstania, rozm. Jadwiga Knie-Górna, „Przewodnik Katolicki” 104(1998) nr 31, s. $10-12$, il.

Fenrych Władysław, Waliszewski Stanisław: Chusta z Oviedo, „W Drodze” 21(1993) nr 6, s. 94-98.

Fenrych Władysław, Waliszewski Stanisław: Krwawe plamy na Całunie a współczesna hematologia, w: Waliszewski Stanisław: Całun Turyński dzisiaj, WAM, Kraków 1987, s. 133-146.

Toż: wyd. 3, 1944, s. 135-146.

ff.: O świętym całunie i Przenajświętszym Obliczu Pana naszego Jezusa Chrystusa, „Przewodnik Katolicki” 43/1937, s. 180-182, il.

(G): Ostatnie badania Całunu z Turynu, „Myśl Społeczna” 39/1968, s. 7.

Gadacz Czesław: Pierwsze trzy sekundy po zmartwychwstaniu, „List” 10/2011, s. 14-18, il.

Gdyk Nikodem: Całun Turyński, „Ziemia Święta” 7(2000) nr 1, s. 21.

Gołąb Stanisław: Prawda zamknięta w całunie, rozm. przepr. Jan Ośko, „Niedziela” 14/2004, s. 14.

Gołubiew Antoni: Jeszcze w sprawie Całunu Turyńskiego, „Znak” 6(1951) nr 6, s. 183-191.

Gorzym A.: Wiara czyni cuda! „Wiedza i Życie” 5/1989, s. 62-65.

Polem.: Skrok Zdzisław: Zagadka Całunu, „Wiedza i Życie” 5/1989, s. 65 .

Góral Kazimierz: Stara i nowa historia Całunu Turyńskiego, „Resovia Sacra. Studia Teologiczno-Filozoficzne Diecezji Rzeszowskiej”2/1995, s. $127-138$. 
Graczyk Maria, Pałasiński Jacek, Wojciechowski Tadeusz: Ślady na płótnie. Całun Turyński pozostaje wielka tajemnica, „Wprost” 17/1998, il.

Grochowski Stanisław: Świadectwo, „Niedziela” 14/2001, s. 14.

Gronkowski Witold: Czy wedtug danych czterech ewangelii Chrystus byt pochowany w catunie?,,Sprawozdania z Posiedzeń Towarzystwa Naukowego Warszawskiego" 13(1945-1946) z. 2, s. 170-173.

Gruca Jerzy: Całun Turyński darem dla Papieża, „Słowo Powszechne” 36(1983) nr 63, s. 1-2.

Gruca Jerzy: Całun Turyński w poważnym niebezpieczeństwie, „,Słowo Powszechne" 36(1983) nr 244, s. 1-2.

Grygiel Ludmiła: „,Józef zabrał ciało, owiną je w czyste płótno...”, ,Tygodnik Powszechny" 32(1978) nr 43, s. 5.

Grzędowicz Jarosław: Twarz Boga, „Gazeta Polska” 14/2004, s. 9-10.

(HP): Wystawienie Całunu Turyńskiego, „Gość Niedzielny” 55(1978) nr 39, s. 3.

Hubicki Ryszard: Całun Turyński. Grobowe płótno Jezusa, „Źródło” 25/2015, s. 8-9.

I. K.: Rok 1978 - Rokiem Całunu, „Gość Niedzielny” 55(1978) nr 8, s. 3.

(IK): Wystawa poświęcona Całunowi Turyńskiemu, „Gość Niedzielny” 56(1979) nr 3, s. 2.

Instytut Federalnej Stużby Bezpieczeństwa Rosji zaangażowany w badania nad Całunem Turyńskim, „Animator” 1/2007, s. 215.

Jakubionek Marcin: Nieznana historia Całunu Turyńskiego, „List” 23(2006) nr 4, s. 36-39, il.

Jan Paweł II: Homilia Ojca Świętego (...) podczas liturgii słowa przed wystawionym w katedrze turyńskiej w dniu 24 maja 1998 r., tłum. Jerzy Chmiel, „Ruch Biblijny i Liturgiczny” 51(1998) nr 3, s. 218-221.

Janczuk Adolf, Kopeć Józef: Całun Turyński, w: Encyklopedia katolicka, TN KUL, Lublin 1976, t. 2, kol. 1288-1290.

Jankowski A.: Tajemnice Turyńskiego Całunu. Czy w tak delikatna i subtelna materię wmieszało się fatszerstwo? „Prawo i Życie” $1991 \mathrm{nr} 2$, s. 15-16, il.

Jaroszek J.: Święty Całun, „Gość Niedzielny” 15/1937, s. 661, 672, 688, 704. Jaworski Jan S.: Między wiedza a wiarą, rozm. przepr. Magdalena Kotwica, Paweł Lubrański, „Przegląd Powszechny” 128(2011) nr 7-8, s. 98-108. Jaworski Jan S.: Identyfikacja monet z Całunu Turyńskiego, „Przegląd Powszechny" 246(1985) nr 2, s. 292-294. 
Jaworski Jan S.: Wyniki ostatnich badań Całunu Turyńskiego, „Przegląd Powszechny" 240(1983) nr 7-8, s. 109-119.

(JK): Całun Turyński, „Gość Niedzielny” 51(1974) nr 9, s. 65.

Jonasz: Całun, „Gość Niedzielny” 66(1989) nr 10, s. 8.

Jotes: Calun Turyński w świetle ostatnich badań, „Rycerz” 4/1985, s. 100-101. (k): Autor „Całunu Turyńskiego” I[an] Wilson w Polsce. Na zaproszenie IW Pax, „Słowo Powszechne” 38(1984) nr 105, s. 6.

Karcz Jan: Tajemnica Całunu Turyńskiego, „Za i Przeciw” 15/1971, s. 8, il. Kaucha Krzysztof: Czy grób naprawdę byt pusty: Całun Turyński w teologii fundamentalnej, ,Roczniki Teologii Fundamentalnej i Religiologii” 4/2012, s. 21-49.

Kim jest człowiek z Całunu? Wystawa kopii Całunu Turyńskiego, [Kraków 2012], s. 28.

Kisielewski Józef, Święty Całun. Wstrząajace odkrycie w Turynie, „Tęcza” 11(1937) t. 1, nr 3, s. 21-22, il.

Kindziuk Milena: Całun „Ikona Zmartwychwstania”, „Niedziela”13/2013, s. 14-15.

Kłoś K.: Całun Turyński - relikwia i... zabytek archeologiczny, „Z Otchłani Wieków" 50(1984) nr 2, s. 114-124, il.

Kłyś A.: Wiara kontra izotop C-14. Czy Całun jest autentyczny, czy jest średniowiecznym falsyfikatem? „Życie Nauki” 1998 z dn. 27 IV, s. 9, il.

Kontrowersje wokół pochodzenia Całunu Turyńskiego, „Słowo Powszechne” 34(1980) nr 274, s. 9, il.

Kościński P.: Idąc ku wielkiej tajemnicy. Najnowsze badania Całunu Turyńskiego, „Tygodnik Demokratyczny” 16/1987, s. 10, il.

Kot A.: Sześć wieków śledztwa. Całun Turyński-najcenniejsza relikwia chrześcijaństwa, „Gazeta Poznańska” 14/1996, s. 2.

Kowalska Antonina: Całun Turyński w świetle nowych badań, „Prace Komisji Filozofii Nauk Przyrodniczych Polskiej Akademii Umiejętności" 3/2009, s. 67-78.

Kraj Jerzy: Kopia Całunu. Dar z Turynu dla Grobu Pańskiego w Jerozolimie, „Ziemia Święta” 10(2004) nr 1, s. 6, fot.

Krajewska E.: Prawda o Catunie Turyńskim, „Przegląd Tygodniowy” 14/1983, s. 8-9, il.

Krzysztof: Jak wygladat Jezus, „Przewodnik Katolicki” 86(1980) nr 8, s. 8 , il.

Krzyżak Tomasz: Autoportret Chrystusa, „Uważam Rze”12/2013, s. 18-19. 
Krzyżak Tomasz: Świadek Zmartwychwstania. Obraz Umęczonego, „Ozon” 22/2006, s. 40-44.

Książek Mariusz: Niemy świadek mitości, „Niedziela” 25/2015, s. 12-13.

Kucewicz Zygmunt: Męka i śmierć Chrystusa w aspekcie medycznym, „Posłannictwo” 31(1962) nr 6, s. 15-18.

Legan Michał: Papieże odsłaniają światu największe skarby, „Niedziela” 26/2015, s. 55.

Lenartowicz Piotr: Kiedy powstat Całun Turyński? „Posłaniec Serca Jezusowego" 7/1989, s. 41, il.

Lenartowicz Piotr: Tajemnica Całunu Turyńskiego, „Posłaniec Serca Jezusowego" 7/1989, s. 120-121, il.

Lewandowska Izabela: Muzeum Całunu w Turynie, „Muzealnictwo” 40/1998, s. 151-156.

Litak Eliza: Byt wysoki i miat warkocz, „List” 23(2006) nr 4, s. 25-32, il.

Litak Eliza: Nauka i Całun, „List” 23(2006) nr 4, s. 34-35, fot.

Litak Eliza: Znajomy wizerunek, „List” 23(2006) nr 4, s. 40-41, il.

Łepkowski Paweł: Catun i prawda. Włochy, „Nasz Czas” 35-36/2010, s. XXIX-XXXI.

Łepkowski Paweł: Trójwymiarowy świadek zmartwychwstania, „Uważam Rze" 13/2013, s. 14-17.

ŁUK, Reuter, KAI: Święte płótno z Turynu, „Życie” 2(1998) nr 91, s. 1, 6.

Łysiak Tomasz: Świadectwo największej miłości, „W Sieci” 20/2015, s. 86-89.

(m. d.): Najnowsze badania potwierdzaja: Calun Chrystusa autentyczny! „Skandale" 1991 z dn. 10 I, s. 6, il.

Machowska R.: Badania nad Całunem z Turynu, „Myśl Społeczna” 14/1974, s. 9, il.

Maciejewski B.: Jak wygladat Chrystus, „Super Express” 267/1994, s. 27, il. Magierowski Marek: Zdjęty wczesnym wieczorem... Inskrypcje na Całunie Turyńskim przyblizaja nas do prawdy. Czy kiedykolwiek ja poznamy? „DoRzeczy” 26/2013, s. 56-58.

Majchrzak Andrzej: Tajemnica Całunu, „Tygodnik Demokratyczny” 30(1983) nr 14, s. 12-13, il.

Makiej Bolesław, Dołęga-Chodasiewicz Jerzy, Fenrych Władysław, Waliszewski Stanisław: L'influenza del reliquiario sulla datazione della Sindone col C-14, „Collegasmento pro Sindone” [Roma] 2/1989 (marzo) s. 34-35. 
Makiej Bolesław, Dołęga-Chodasiewicz Jerzy: Najnowsze hipotezy utworzenia się wizerunku na Całunie turyńskim, w: Waliszewski Stanisław: Catun Turyński dzisiaj, WAM, Kraków 1994, s. 177-185.

Makiej Bolesław: The possibilities that Shroud is a hologram of reflected light, w: Sebastiano Rodante (red.), La Sindone. Indagini scientifiche. Atti del IV Congresso Nazionale di Studi sulla Sindone. Siracusa, Edizioni Paoline, Roma 1987, s. 214-216.

(MD): Liczne pielgrzymki do Św. Całunu, „Słowo Powszechne” 32(1978) nr 207, s. 5.

Memches Filip: Zagadka Całunu Turyńskiego, „Uważam Rze” 21/2011, s. 88-90.

Na stynnym Catunie turyńskim fotografia ciała Chrystusa, „ABC” 12(1937) nr 99, s. 9.

Nauka bada oblicza Chrystusa, „Polska”32/2011 (dodatek „The Times”), s. 3.

Nauka wyjaśnia ślady św. Całunu w Turynie, „Głos Narodu” 44(1937) nr 62, s. 4.

Naumowicz Józef: Całun wciąz zagadka, w: Jan Pawet II - Kolekcja, Księga Świętych, Edipresse, Warszawa 2002, s. 28-29.

Nowe światto na stare dokumenty dotyczace św. Całunu w Turynie, oprac. na podst. „L'Osservatore Romano”, „Życie Katolickie” 11/1957 z dn. 23-24 XI, s. I.

Toż: „Słowo Powszechne” 11(1957) nr 280, s. 1, il.

Nulecki A.: Tajemniczy Całun, „Wprost” 51-52/1987, s. 34-35, il.

O autentyczność Catunu Turyńskiego. Przeglad prasy, „Tygodnik Powszechny" 6(1950) nr 49, s. 7.

Olszewski I.: Fotografia Chrystusa, „Rodzina Polska” 13/1939, s. 51-55, il.

Orliński Wojciech: Chemia Boskiego portretu, „Gazeta Wyborcza” [Magazyn] 1998 z dn. 20-2 II, s. 30-34.

P.: Św. Catun (Wystawa poświęcona badaniom uczonych amerykańskich nad Całunem Turyńskim), „Myśl Społeczna” 48/1981, s. 9.

Pabis Małgorzata: Tego chce ode mnie Bóg, „Cuda i Łaski Boże. Miesięcznik Rodzin Katolickich" 4/2007.

Wspomnienia prof. Stanisława Waliszewskiego.

Parol D.: Catun rzuca na kolana, „Echo Dnia” 103/1995, s. 10, fot.

Partyka Jan Stanisław: Acheropity bizantyjskie, „Miejsca Święte” 4/2002, s. 16-19, fot.

Partyka Jan Stanisław: Kolebka mandylionu. Edessa, „Miejsca Święte” 12/2010, s. 24-26, fot. 
Partyka Jan Stanisław: Najstarsze wizerunki Jezusa Chrystusa, „Miejsca Święte" 4/2002, s. 12-15, fot.

Partyka Jan Stanisław: Veraikon, „Miejsca Święte” 4/2002, s. 20-23, il.

[Paygert Adam] A.P.: Całun Turyński w świetle badań, cz. 1-4, „Za i Przeciw" 1978: cz. 1: Największa relikwia chrześcijaństwa, nr 32 s. 9, il.; cz. 2: Wizerunek na płótnie cenniejszy od fotografii, nr 33 s. 9, il; cz. 3: Dzieje ,obrazu Chrystusa nie uczynionego ludzka ręka”, nr 34 s. 8, il.; cz. 4: Relikwia na wieki otoczona kultem, nr 35 s. 8, il.

Piasecki Stanisław: Fotografia sprzed dziewiętnastu wieków, „Myśl Polska” 16-17/2007, s. 12.

Przedruk z „Prosto z Mostu” 15-16/1937.

Poczta Ojca Malachiasza: [Całun z Turynu], „Tygodnik Powszechny 16(1962) nr 6, s. 8.

Toż w: Żychiewicz Tadeusz: Poczta Ojca Malachiasza, t. 1, Znak, Kraków 1970, s. 82-86.

Polczyk Waldemar: Świadek wiary. Refleksje na temat Całunu Turyńskiego, „Ziemia Święta” 7(2001) nr 1, s. 18-21, fot.

Polewska Aleksandra: Dokumenty z procesu Jezusa, „Opiekun” 20/2014, z dn. 28 IX -11 X 2014, s. 29, il.

Polewska Aleksandra: Legendarna relikwia z Edessy, „Opiekun” 3/2013 z dn. 2-15 II 2013, s. 36-37, il.

Polkowski Andrzej: Milczacy świadek [całun], rozm. przepr. Adam Cymer, „Zorza” 51/1983, s. 18-19, il.

Prawdziwość Całunu. Pytania - odpowiedzi, „Gość Niedzielny” 55(1978) nr 48, s. 383.

R.: Całun [sympozjum w Londynie], „Myśl Społeczna 43/1977, s. 11.

R.: Sprawa św. Całunu z Turynu, „Myśl Społeczna” 16/1978, s. 10.

R.: Św. Całun, „Myśl Społeczna” 36/1978, s. 11.

R.: Turyński święty Całun, „Myśl Społeczna” 11/1978, s. 11.

R.F.: W oczekiwaniu wystawienia św. Całunu, „Kurier Poznański”156/1931, s. 3-4.

Rostworowski Marek: Raport w sprawie Całunu Turyńskiego, „Słowo Powszechne" 35(1981) nr 198.

[Róziewicz Jerzy] J.R.: V Colloque International de Sinologie (Chantilly, 15 -18 IX 1986), „Kwartalnik Historii, Nauki i Techniki” 32(1987) nr 2, s. 525 .

Ryszka Czesław: Tajemniczy Całun, „Katolik” 5/1989. 
Rzepka Mirosław: To jest płótno grobowe Jezusa. Badacz Całunu Turyńskiego [Jerzy Dołega-Chodasiewicz] u oblatów na Koszutce, „Gość Katowicki” [dodatek do „Gościa Niedzielnego”] z 18 III 2007, s. X-XI.

(S. K.): Problem Całunu Turyńskiego. W programie telewizji włoskiej, „Słowo Powszechne” 27(1973) nr 285, s. 1-2, il.

S. W.: Dyskusja o Catunie z Turynu, „Przewodnik Katolicki” 96(1990) nr 28.

Saczkowski Wiktor: Catun Turyński. Nowe dowody i nowe znaki zapytania, „Przewodnik Katolicki” 88(1982) nr 5-6, s. 2-3.

Sakiewicz T.: Całun wciąż jest zagadka, „Gazeta Polska” 14/1996, s. 2, il.

Seweryniak Henryk, Archeologia o Jezusie, „Studia Płockie” 27/1999, s. 221-228.

Sieradzki Jerzy: Bezcenny dokument, „Tygodnik Katolicki” 5(1950) nr 12, s. 86-87.

Skowronek Alfons: Tajemnica Zmartwychwstania, „Ład” 2(1982) nr 1, s. 3. Skrok Zdzisław: Całun Turyński - zagadki ciag dalszy..., „Wiedza i Życie” 3/1989, s. 48-53, il.

Spotkanie z autorem „Calunu Turyńskiego” [Ianem Wilsonem w tódzkim Klubie PAX, 26 maja 1984], „Słowo Powszechne” 38(1984) nr 106, s. 2.

Sprutta Justyna: Ikona ,Mandylion” a Catun Turyński, „Studia Gnesnensia” 20/2006, s. 243-261.

Stachnik Paweł: Całun Turyński. Świadek męki i zmartwychwstania Chrystusa, fot. Michał Klag, „Wiara, Patriotyzm i Sztuka” 11/2012, s. 40-42, fot.

Starowieyski Marek: Całun i mandylion, „Przewodnik Katolicki” 74(1986) nr 110, s. 3.

Stefaniak Ludwik, Całun Turyński, w: Podręczna encyklopedia biblijna, Księgarnia św. Wojciecha, Poznań 1959, t. I, s. 202-205.

Stopniak Franciszek: Calun Turyński-pośmiertne płótno Jezusa, „Słowo Powszechne" 38(1984) nr 82, s. 3-7.

Stylińska Teresa: Obraz nienamalowany, „Rzeczpospolita” 90/2015, s. 10-11. Stylińska Teresa: Pasja Chrystusa, pasja człowieka. Najstynniejsza relikwia chrześcijaństwa, „Tygodnik Powszechny” 14/2010, s. 30-31.

Surwiłło Michał [oprac.]: Czy całun jest relikwia?? „Myśl Społeczna” 38/1978, s. 5, il.

Szafrański Włodzimierz: Prześcieradło grobowe Jezusa, „Argumenty” 18(1974) nr 24, s. 1, 11, il.

Szewc Eugeniusz: Całun turyński w świetle nauki Biblii, „Wiadomości Archidiecezji Łódzkiej" 50(1976) nr 3, s. 61-68. 
Szostkiewicz Adam: Tajemnica płótna, „Polityka” 14/2010, s. 20-23.

Szperacz: Całun Turyński autentyk czy falsyfikat? „Życie Katolickie” 16(1962) nr 27, s. II.

Toż: „Słowo Powszechne” 16(1962) nr 35.

Szrant Karol: Kongres syndologów [Turyn 1950], „Homo Dei” 19(1950) nr 1, s. 146-152.

Szymeczko Jan: Całun Turyński, „Słowo Powszechne” 7(1953) nr 32, s. 1, il. Święty Całun a nauka [II Międzynarodowy Kongres w Turynie], „Gość Niedzielny" 56(1979) nr 43, s. 2.

[Tajemnica Całunu Turyńskiego], „Jezus Żyje” [Mogilany] 9/1999.

Treść: Najstynniejsza tkanina świata, s. 4-5; Identyfikacja mężczyzny z całunu, s. 6-7; Ten człowiek przeżyt straszliwą męke, s. 8-9; Umart na krzyżu, s. 10-11; Przebite serce, s. 11; Pogrzeb, s. 12; Ujrzat i uwierzyt, s. 13; Nazarejczyk, s. 14; Intrygujące zbieżności, s. 15-16; Ta sama grupa krwi: AB, s. 17; Co mówi historia, s. 18-19; Metoda izotopu węgla C14, s. 20-21; Hipoteza fatszerstwa, s. 22; Trzeba powrócić do badania pytków, s. 22-23; Rzymskie monety na oczach, s. 23; Nie ręka ludzka malowany, s. 24; Świadectwa uczonych, s. 24-25; Całun Turyński-dziełem sztuki? s. 28.

Tarnowski Krzysztof: Całunu Turyńskiego przypadek wyjątkowy, „Przegląd Powszechny"128(2011) nr 12, s. 117-125.

Teinert Zbigniew: Jeszcze o Całunie Turyńskim, „Przewodnik Katolicki 95(1989) nr 10, s. 5.

(TS): Rok Całunu Turyńskiego, „Słowo Powszechne” 32(1978) nr 42, s. 5, il. [Turowicz Jerzy] J. T.: Całun Turyński w telewizji, ,Tygodnik Powszechny” 28(1974) nr 6, s. 1-2, il.

Twardziłowski Tomasz: Ewangeliczne opisy męki i zmartwychwstania Jezusa a wizerunek na Catunie Turyńskim, „Zeszyty Formacji Katechetów" 13(2013) nr 4, s. 48-58.

Twardziłowski Tomasz: Funkcja tkanin w ewangelicznych narracjach o pogrzebie i zmartwychwstaniu Jezusa, w: tenże (red.), Zmartwychwstanie. Szkice biblijne i teologiczne, Koło Naukowe Doktorantów Biblistyki, Warszawa 2015, s. 61-90.

Twardziłowski Tomasz: Passio Christi. Passio hominis. Śladami Całunu Turyńskiego, „Biuletyn Koła Naukowego Studentów UKSW” 3/2010, s. $18-20$.

Tyszka Zygmunt: Próba kradzieży Św. Całunu Turyńskiego, „Słowo Powszechne" 33(1979) nr 105, s. 2. 
Tyszka Zygmunt: Zakończyło się wystawienie Całunu Turyńskiego, „Słowo Powszechne" 32(1978) nr 232, s. 1-2.

(W): ,Gdyby całun byt prawdziwy...”, „Problemy Wyznań i Laicyzacji” 12(1970) nr 26, s. 16-17.

(W.): Wystawa Świętego Całunu w Lizbonie, „Słowo Powszechne” 11(1957) nr 129, s. 1.

Waliszewski Stanisław: Badacz Całunu Turyńskiego [Władysław Fenrych], „Przewodnik Katolicki” 35/2003.

Waliszewski Stanisław: Całun Turyński oczami lekarza, „Ruch Biblijny i Liturgiczny" 37(1984) nr 5, s. 432-447; nr 6, s. 524-540.

Waliszewski Stanisław: Całun Turyński w naszych oczach $i$ oczach naszych dziadków, „Przewodnik Katolicki” 93(1987) nr 17, s. 6, il.

Waliszewski Stanisław: Całun z Cadouin, „Gość Niedzielny” 54(1977) nr 25, s. 9.

Waliszewski Stanisław: Całun z Turynu, cz. 1-6, „Kurier Rogoziński” 1993-1994: cz. 1: Calun Turyński nie jest tworem średniowiecza, jest autentycznie ewangeliczny, nr 7 s. 7; cz. 2, nr 8, s. 9; cz. 3, nr 9, s. 14; cz. 4: Refleksje, nr 10, s. 12; cz. 5-6: Uczeni wielkiej miary za autentycznościa Całunu Turyńskiego, 3/1994, s. 15; nr 4, s. 15.

Waliszewski Stanisław: Całun z Turynu. W świetle wspótczesnej nauki, cz. 1-2, „Gość Niedzielny” 54(1977) nr 37, s. 293-294; nr 30, s. 309-310.

Waliszewski Stanisław: II Międzynarodowy Kongres w Turynie, Całun w świetle nauki, „Gość Niedzielny” 56(1979) nr 1, s. 7; nr 2, s. 5.

Waliszewski Stanisław: Il Dottor Stanislao Karwowski araldo della Sindonologia Polacca, „Collegamento pro Sindone” [Roma] 6/1988 (agosto), s. 49-50.

Waliszewski Stanisław: Jeszcze o Catunie z Turynu, „Tygodnik Powszechny" 27(1973) nr 21, s. 3.

Waliszewski Stanisław: Medycyna o śmierci Chrystusa, „Gość Niedzielny” 55(1978) nr 12, s. 4.

Waliszewski Stanisław: Nowe stwierdzenia w sprawie Całunu Turyńskiego. Sprawozdanie ze Zjazdu Syndonologicznego w Trani 1984, „Ruch Biblijny i Liturgiczny" 38(1985) nr 6, s. 409-416.

Waliszewski Stanisław: Oddziaływanie Całunu Turyńskiego na wczesnochrześcijańska ikonografię, „W Drodze” 11(1983) nr 4, s. 38-48.

Waliszewski Stanisław: Uwagi o Catunie Turyńskim, „Ruch Biblijny i Liturgiczny" 6(1953) nr 1-6, s. 50-74, addenda s. 223; 7(1954) nr 3-6, s. 68-106. 
Waliszewski Stanisław, Fenrych Władysław: Spór o Całun Turyński, „W Drodze” 16(1989) nr 3, s. 85-91.

Wasylczyk Piotr: Całun w świetle lasera. Najnowsze badania płótna z Turynu, „Tygodnik Powszechny” 3/2012, s. 17.

Weber Bożena: Kim jest Człowiek z Całunu? „Źródło” 14/2014, s. 18-19.

Widurski Michał: Catun Turyński, [cz. 1-3], „Opiekun” 2012: [cz. 1]: Matka wszystkich relikwii, nr 7, il.; [cz. 2]: Datowanie, nr 8, il.; [cz. 3]: Najnowsze odkrycia, $\mathrm{nr}$ 9, il.

Wojciechowski J.: Nowe dowody autentyczności Całunu Turyńskiego, „Zorza" 47/1977, s. 7.

Wojciechowski Marcin: Autentyczność całunu turyńskiego w świetle krytyki naukowej, „Życie Literackie” 9(1955) nr 43, s. 1-2, il.

Wojciechowski Michał: Co z tym Catunem? „Familia” 7/2010, s. 67, il.

Wojciechowski Michał: Tajemnica Całunu Turyńskiego, „Tygodnik Północny" 21/1992, s. 1-2.

(Y): Nowe badania nad Całunem Turyńskim, „Gość Niedzielny” 53(1976) nr 16, s. 127.

Zając Wojciech: Całun Turyński widziany oczyma fizyka, czyli dialog rozити z wiara, „Rocznik Seminaryjny. Biuletyn Informacyjny Wyższego Seminarium Misyjnego Zgromadzenia Księży Najświętszego Serca Jezusowego w Stadnikach" 2/2002-2003, s. 217-225.

Zborski Bartłomiej: Całun z Turynu, „Lad” 2(1982) nr 1, s. 3, il.

Ziółkowski Zenon: Całun grobowy Jezusa. Zagadka archeologiczna (1-4), „Kierunki” 18(1974) nr 34, s. 1, 4, il.; nr 35, s. 4, il.; nr 36, s. 4; nr 37, s. 4, il.

Ziółkowski Zenon: Całun Turyński, „Miejsca Święte” 4/1998, s. 9-23.

Ziółkowski Zenon: Całun Turyński, „Niedziela” 14/1998, s. 10, il.

Ziółkowski Zenon: Całun Turyński nadal strzeże swojej tajemnicy, „Zorza” 2/1989, s. 8 .

Ziółkowski Zenon: Catun Turyński. Świadectwo zmartwychwstania Chrystusa, „Zorza” 1/1982, s. 4-5, il.

Ziółkowski Zenon: Całun Turyński w literaturze polskiej (układ chronologiczny), w: Wilson Ian: Całun Turyński, Instytut Wydawniczy Pax, Warszawa 1983, s. 343-346.

Ziółkowski Zenon: Całun Turyński w świetle najnowszych badań, „Życie i Myśl" 24(1974) nr 4, s. 23-31, il.

Ziółkowski Zenon: Całun Turyński - zagadka fotograficzna, „Słowo Powszechne" 43/1990 z dn. 10-12.8, il. 
Ziółkowski Zenon: Człowiek z Całunu Turyńskiego, „Słowo Powszechne” 32(1978) nr 223, s. 6-7.

Ziółkowski Zenon: Czy Chrystus ,,stracił Całun”, wywiad z (...), „Słowo Powszechne" 42(1989) nr 2, s. 8-9.

Ziółkowski Zenon: Elektroniczne badania nad życiem $i$ śmiercia Jezusa. Ten spór trwa już od wieków, „Słowo Powszechne” 27(1973) nr 197, s. 3-4, il.

Ziółkowski Zenon: Jan Paweł II w mieście Całunu, „Kierunki” 25(1980) nr 15, s. 4, il.

Ziółkowski Zenon: Jedna z tajemnic Całunu Turyńskiego, „Kierunki” 30(1984) nr 5, s. 1, 5, il.

Ziółkowski Zenon: Mandylion. Śladami Całunu Turyńskiego, „WTK” 14/1974, s. 1, 3, il.

Ziółkowski Zenon: Międzynarodowy Kongres o Całunie Turyńskim [Londyn], ,Słowo Powszechne” 31(1977) nr 269, s. 6-7.

Ziółkowski Zenon: Najnowsze badania naukowe nad Całunem Turyńskim, „Życie i Myśl” 29(1979) nr 7-8, s. 58-74, il.

Ziółkowski Zenon: O Całunie Turyńskim - nie wszystko, „Słowo Powszechne" 32(1978) nr 217, s. 7, il.

Ziółkowski Zenon: Śladami Chrystusa. Krzyż i Całun, „WTK” 21(1973) nr 14, s. 3, il.

Ziółkowski Zenon: Średniowieczne fałszerstwo? „Kierunki” 26(1981) nr 38, s. 4, il.

Ziółkowski Zenon: Tajemnica Całunu Turyńskiego, cz. 1-6, „WTK” 1978: cz. 1, nr 27, s. 1, 3, il.; cz 2: W cieniach i blaskach historii, nr 28, s. 3, il.; cz. 3: Malowidło czy antyczna relikwia, nr 29, s. 3-4, il.; cz. 4: Makabryczne fatszerstwo? nr 30, s. 3, il.; cz. 5: Chrystus czy ktoś inny, nr 31, s. 3-4, il.; cz. 6: Ewangelie przeciw autentyczności, nr 32, s. 3-4, il. Ziółkowski Zenon: Znak 2010 roku. Od 10 kwietnia do 23 maja 2010 roku będzie wystawiony Catun Turyński, „Miejsca Święte” 4/2010, s. 4-10, il., fot.

Żarska Dorota: Tajemnica Świętego Oblicza, „Miejsca Święte” 4/1998, s. 24-25.

\section{Autorów zagranicznych}

Allen Conrad: Twarz Chrystusa, tłum. Maria Tarnowska, „Tygodnik Powszechny" 21(1967) nr 13, s. 1, 9, il. 
Baima Bollone Pierluigi: Nauka potwierdza przeczucia (Całun Turyński), rozm. z prof. (...) przeprowadziła Irena Burchacka, „Za i Przeciw” 28/1984, s. 7.

Baima Bollone Pierluigi: Naukowiec na tropie tajemnic, z badaczem Catunu Turyńskiego... rozm. Grzegorz Górny, „W Sieci” 31-32/2013, s. 62-63 (dodatek „Sanktuaria. Madonny. Pielgrzymki”).

Barberis Bruno: Całun Turyński dla nauki, rozm. przepr. Agnieszka Gracz, „Nasz Dziennik” (wyd. 2) 9/2012, s. 19.

Barberis Bruno: Znak naszych czasów. Wzrastać w wierze, rozm. przepr. Katarzyna Urnan, „Źródło” 17/2011, s. 10-11.

Barford Paul M.: The original form of the Turin Shroud. The Archeology of the Medieval religious mind, „Fasciculi Archeologiae Historicae” 12/1999, s. 37-46.

Benedykt XVI: Rozważanie Ojca Świętego (...) przed Całunem - Turyn, 2 V 2010 r., „Kielecki Przegląd Diecezjalny” 86 (2010) nr 4, s. 400-403. Claudel Paweł: Fotografia Chrystusa (list do Girard-Cordonier), „Dziś i Jutro" 2(1946) nr 16, s. 1, il.

Coero Piero: Całun relikwia całego chrześcijaństwa, rozmowa (...) z Międzynarodowego Ośrodka Syndonologicznego, „Za i Przeciw” 25/1984.

Daniel-Rops Henri: Czy widzieliście prawdziwe oblicze Chrystusa? „Słowo Powszechne" 11(1957) nr 82, s. III, il.

Daniel-Rops Henri: Tajemnicze oblicze z Całunu Turyńskiego, w: tenże, Dzieje Chrystusa, tłum. Zofia Starowieyska-Morstinowa; wstęp Eugeniusz Dąbrowski, Instytut Wydawniczy Pax, Warszawa 1972², s. 563-569.

Danin Avinoam: Z bliska i daleka, rozm. przeprowadził Grzegorz Dobroczyński, „Przegląd Powszechny” 128(2011) nr 7-8, s. 109-114.

Delclaux Adrieni: Rozważanie o Catunie Turyńskim, tłum. Jerzy Brzozowski, ,Znak” 37(1985) nr 365, s. 135-150.

De Mattei Roberto: Zwierciadło Ewangelii. Tajemnica Całunu Turyńskiego, tłum. Anna Bałaban, „Nasz Dziennik” (wyd. 2) 95/2015, s. 17.

Féret Henri-Marie: Blyskawica grobu. Ewangelia i Całun Turyński, mówi (...), dominikanin, profesor hermeneutyki biblijnej, „Za i Przeciw” 14/1988, s. 10.

Féret Henri-Marie: Historyk wobec catunu turyńskiego, rozm. z (...), „Za i Przeciw" 41/1984.

Fernandez-Capo Josep: Faith and science dialogue in the Shroud of Turin, „Scientia et Fides. Półrocznik Wydziału Teologicznego Uniwersytetu Mikołaja Kopernika” 3(2015) nr 1, s. 37-59. 
Ferreri Guliano: Całun Turyński. Nowe pytania, „Głos Wielkopolski” 3/1991, s. 5.

Ferrier Jacques: Czy święty Catun wystawiony w Turynie jest autentyczny? „Za i Przeciw” 4/1978, s. 8, il.

Guerreschi Aldo: Acheiropoietos nie ręka ludzka uczyniony, rozm. przepr. Jacek Molka, „Niedziela” 28/2014, s. 19-20.

Guerreschi Aldo: Calun wciaż jest tajemnica. Do 24 czerwca w katedrze św. Jana w Turynie wystawiony jest na widok publiczny Catun Turyński, z badaczem... rozm. Grzegorz Górny, „W Sieci” 19/2015, s. 102-105.

Guerreschi Aldo: Czlowiek zawinięty w catun mial grupę krwi AB. I bardzo cierpiat, rozm. przepr. Grażyna Starzak, „Polska” 27/2015, s. 3.

Habermas Gary R., Stevenson Kenneth E.: Werdykt w sprawie Catunu, tłum. Andrzej Polkowski, „Katolik” 17/1984; 20/1984; 21/1984; 23/1984; 24/1984;

Hynek Rudolf: Nauka fotografuje męczone ciało Chrystusa, „Tęcza” 11(1937) t. 1, nr 3, s. 23-29, il.

I. D.: Sprawa „Turyńskiego Catunu”, oprac. na podstawie artykutu Davida Soxa: The authenticity of the Turin shroud. „The Clergy Review” 1978 $n r 7$ s. 250-256, „Novum” 22(1979) nr 2, s. 167-169.

Maik Jerzy: The Shroud of Turin as a historical textile, tłum. Zuzanna Poklewska-Parra, „Fasciculi Archeologiae Historicae” 12/1999, s. 47-49.

Maillard Stanislas: Czy Całun jest autentyczna relikwia? tłum. Irena Kownacka, „W Drodze” 6(1978) nr 9, s. 99-101.

Owen Richard: Świat ponownie zobaczy stynny catun turyński, „Polska” 79/2010 (dodatek „The Times”), s. 4-5.

Ricci Giulio: Całun - dokument z pogranicza nauki i wiary w świetle najnowszych dokumentów, „Za i Przeciw” 39/1987, s. 17; nr 40, s. 19, 23; nr 41, s. 18; nr 42, s. 18; nr 43, s. 17; nr 44-47, s. 17; nr 48, s. 19.

Riggi di Numana G.: Rozstrzygnięcie chwilowe [wywiad przepr. Lucien Even], „Za i Przeciw” 51-52/1988, s. 8, il.

Rinaldi P.: The Man in the shroud, London 1974. Fragm.: Catun Turyński, tłum. Władysław Fenrych, „Przewodnik Katolicki 82(1976) nr 15, s. 4-5, il.

Schloemer Blandina Paschalis: Jestem tu, aby adorować i kontemplować oblicze wcielonego Boga, rozm. przeprowadził Włodzimierz Rędzioch, „Niedziela” 53(2010) nr 12, s. 10-11, fot.

Schvandt L.: Całun Turyński żyje! „Rewelacje” 11/1995, s. 4-9, il. 
Solimeo Plinio Mario: Męka Pańska wedtug Całunu Turyńskiego, „Przymierze z Maryją" 9/2003, fot.

Stevenson Kenneth E., Habermas Gary R.: Prawda Całunu, „Za i Przeciw” 29-40/1984; 42-50/1984.

Tamburelli Giovanni: Prawdziwe oblicze, wywiad przepr. Lucien Even, „Za i Przeciw” 28/1986, s. 3-4.

Wilson Ian: Całun jest ",milczacym świadkiem” zwycięstwa nad śmiercia, rozm. z (...), „Słowo Powszechne” 38(1984) nr 111.

Wilson Ian: Calun z Turynu a archeologia Nowego Testamentu, thum. Krystyna Karwowska, „W Drodze” 11(1983) nr 4, s. 32-37.

Wilson Ian: Czy największa relikwia chrześcijaństwa? tłum. Jadwiga Piątkowska, cz. 1-3, „Za i Przeciw” 1980: cz. 1: Tajemnica Całunu, nr 17, s. 8, il.; cz. 2: Jak rozumiano catun do roku 1973, nr 18, s. 8, il.; cz. 3: Kamera ujawnia, nr 19, s. 8, il.

Wilson Ian: Dzieje „Świętego Całunu”, tłum. I. D., „Novum” 17(1974) nr 11-12, s. 76-84.

Wilson Ian: Nie jestem dogmatykiem, rozm. z (...) autorem „Całunu Turyńskiego”, „Kierunki” 30(1984) nr 27.

Wilson Ian: Tajemnice Całunu Turyńskiego, rozm. z dr (...), „Zorza” 28/1984 nr 28. 